\title{
Bt crops: Predicting effects of escaped transgenes on the fitness of wild plants and their herbivores
}

\author{
Deborah K. LETOURNEAU ${ }^{1, *}$, Gaden S. ROBINSON ${ }^{2}$ and Joy A. HAGEN ${ }^{1}$ \\ ${ }^{1}$ Department of Environmental Studies, University of California, Santa Cruz, USA \\ ${ }^{2}$ Department of Entomology, The Natural History Museum, London, UK
}

One prominent concern about genetically modified crops is the possibility of environmental impacts from the movement of fitness-enhancing traits to wild plant populations. Decisions to deregulate $B t$ crops in the USA have relied strongly on arguments that these crops will not interbreed with wild relatives in the permitted growing regions. Limited attention therefore has been directed to analyses of the consequences of gene flow. To provide a transparent evaluation process for risks associated with insecticidal transgene escape, we crafted a series of questions designed to guide this aspect of the risk assessment. We then explored the current knowledge base available for answering such risk-related questions for three $B t$ crops (cotton, rapeseed, and rice). First, we generated a list of wild relatives of these crops. A definitive list of potential transgene recipients is not yet possible for some crops. Sufficient data are not available for some crops to eliminate certain related plant species from consideration of fertile hybrid formation, thus making lists for these crops subject to speculation. Second, we queried the HOSTS database (UK) to obtain a worldwide listing of lepidopteran species that feed on these crops and their wild relatives, and to determine the host range of the larvae. To our knowledge, this list of $\mathbf{5 0 2}$ lepidopteran species is the first such list published for these crops and wild crop relatives. Third, we used a data set maintained by the Canadian Forest Service to assess $B t$ toxin susceptibility for these lepidopterans. Only $3 \%$ of those species have been tested for susceptibility; and the literature suggests that generalizations about susceptibility among taxa are difficult due to the variability within families. Fourth, we consulted the literature to interpret what is known about the ability of lepidopterans to regulate plant fitness or invasiveness. We could not eliminate the possibility of ecological release due to plant resistance against lepidopterans. In fact, there is strong experimental evidence that lepidopteran herbivores do limit the distribution and/or abundances of at least some wild plant species. Neither could we eliminate the possibility that non-target lepidopterans might have important functions in the ecosystem as pollinators or alternate hosts to natural enemies of pest species. This study suggests that crucial data are lacking for the development of a credible scientific basis to confirm or deny environmental risks associated with the escape of Bt transgene constructs to wild relatives. Given the absence of information on the identity, level of susceptibility, and ecological roles of lepidopterans exploiting specific wild relatives of Bt crops, we suggest that new efforts be directed to assessing possible consequences of lepidopteran mortality on resistant wild relatives.

Keywords: $B t$ cotton / Bt rapeseed / Bt broccoli / Bt rice / superweed / risk assessment / biosafety / Lepidoptera / herbivores / insect-resistant crops / host plant database

\section{INTRODUCTION}

A wide range of crop plants and trees have been transformed with genes derived from the soil bacterium Bacillus thuringiensis $(B t)$ to express insecticidal proteins (insect-resistant $B t$ plants), including corn, soybean, rice, tomato, broccoli, coffee, poplar, and Loblolly pine. Whereas the adoption of $B t$ plants constitutes one of the most common uses of transgenic plants in agriculture, the environmental benefits and risks remain an issue of

\footnotetext{
* Corresponding author:
}

Fax: 831-459-4015; e-mail: dletour@ucsc.edu 
contention. Bt plants have been promoted as beneficial to the environment because (1) the resistance mechanism is specific, affecting few but the target taxa and (2) Bt based host plant resistance allows for reduced pesticide use (Betz et al., 2000; Peferoen, 1997; Phipps and Park, 2002). Both taxon-specific pesticidal properties and reduced pesticide usage are key components of integrated pest management strategies designed to promote biological control through the conservation of natural enemies (Barbosa, 1998; Hull and Beers, 1985; Mullin and Croft, 1985). Researchers have called for a variety of assessments, to quantify each of the environmental benefits of $B t$ crops, including (1) adequate tests of lethal, sub-lethal, direct, and indirect effects of $B t$ toxins in plants on non-target and/or beneficial organisms (Hilbeck, 2002; Obrycki et al., 2001; Pilson and Decker, 2002; Saxena et al., 1999; Srinivasan and Babu, 2001), (2) measures of actual pesticide reduction with $B t$ plants, whose range of pests is broader than lepidopterans (Benbrook et al., 1996; Wolfenbarger and Phifer, 2000), and (3) alternative standard comparisons beyond Bt- and non-Btisolines under conventional crop management practices to assess environmental benefits, such as performance of the crop under organic or biological management practices (NRC, 2002; Peterson et al., 2000; Wolfenbarger and Phifer, 2000). Even more common are calls for the assessment of environmental impacts involving gene escape from Bt plants (Hails, 2000; Royal Society of Canada, 2001). Bt toxin based pest resistance is a trait that, should it escape (be transferred to wild plants), could also protect recipient plant populations from damage by susceptible herbivores. Traits such as insect resistance are of special concern because they may relieve a wild plant of some of its natural constraints to population growth. Such an ecological release may increase the population densities or range of occurrence of that plant, thereby increasing weediness or creating a weedy condition (Bergelson and Purrington, 2002; Klinger, 2002; Snow and Palma, 1997; Snow et al., 2003). Increased fitness, competitive ability, and invasiveness of a crop's wild relatives has been a primary concern of research ecologists and regulatory agencies as transgenes conferring novel forms of pest resistance have been incorporated into a range of cultivated plant varieties (Colwell et al., 1985; Darmency, 1994; Hails, 2000; Hoffman, 1990; Kareiva et al., 1994; Louda, 1999; Royal Society of Canada, 2001; Tiedje et al., 1989).

We consider the specific case of the novel resistance trait of $B t$ endotoxin expression against lepidopterans and the potential of such a trait, if it should be expressed in wild relatives of crop plants, to cause a change in weed status of those wild plants. If lowered herbivory on a strongly resistant host plant leads to increased fitness of that plant through various avenues, including increased photosynthetic capacity, vigor, seed output and seed weight, these changes might result in greater levels of invasiveness. Greater levels of invasiveness result in problems such as increased revenues for weed control, displacement of desired or native vegetation, reduced crop yields, loss of refugia for susceptible herbivores, and/or loss of biodiversity through increased mortality of non-target lepidopterans. Whether or not such potential hazards are realized, however, depends on a series of events, each with its own conditions and levels of uncertainty (Bergelson and Purrington, 2002; Jenczewski et al., 2003). These events include (1) the successful transfer of a transgenic trait to a particular wild relative of the crop; (2) an increase of the genetic construct and the resistant phenotype in the recipient population; and (3) some resulting hazard associated with that trait in the environment (such as those listed above). While significant research on the rate and success of transfer of transgenic traits to wild relatives has been achieved for several crop-wild relative combinations (e.g. Chèvre et al., 2000; Jørgensen and Andersen, 1994; Lefol et al., 1997; Messeguer et al., 2001; Mikkelsen et al., 1996; Song et al., 2003), less research has focused on the subsequent hazards of such gene flow.

Critical questions for identifying potential hazards of lepidopteran-resistant $B t$ crops and assessing the probabilities of such an effect occurring include: Which wild plant populations could receive transgenes from these crops through pollen transfer? Which lepidopterans feed on these host plants? What subset of these lepidopterans is susceptible to the endotoxins produced by the related $B t$ crop? Do lepidopterans play a role in regulating those plant populations? Which plants, under what circumstances, when released from herbivory, will exhibit higher fitness? Over time, will the plant population spread or become invasive? What are other possible effects of $B t$ toxins, including direct effects on lepidopteran population dynamics (for example, pollinators of other plant species and reduction of parasitoid reservoirs due to high larval mortality) and direct or indirect effects on other organisms?

Our main objective here is to demonstrate a sciencebased approach to environmental biosafety assessment for transgene escape from transgenic, insect-resistant crops, and to illustrate the state of knowledge and resources currently available to answer ecological questions relevant to that assessment. We offer a flow diagram (Fig. 1) that incorporates such questions in a 


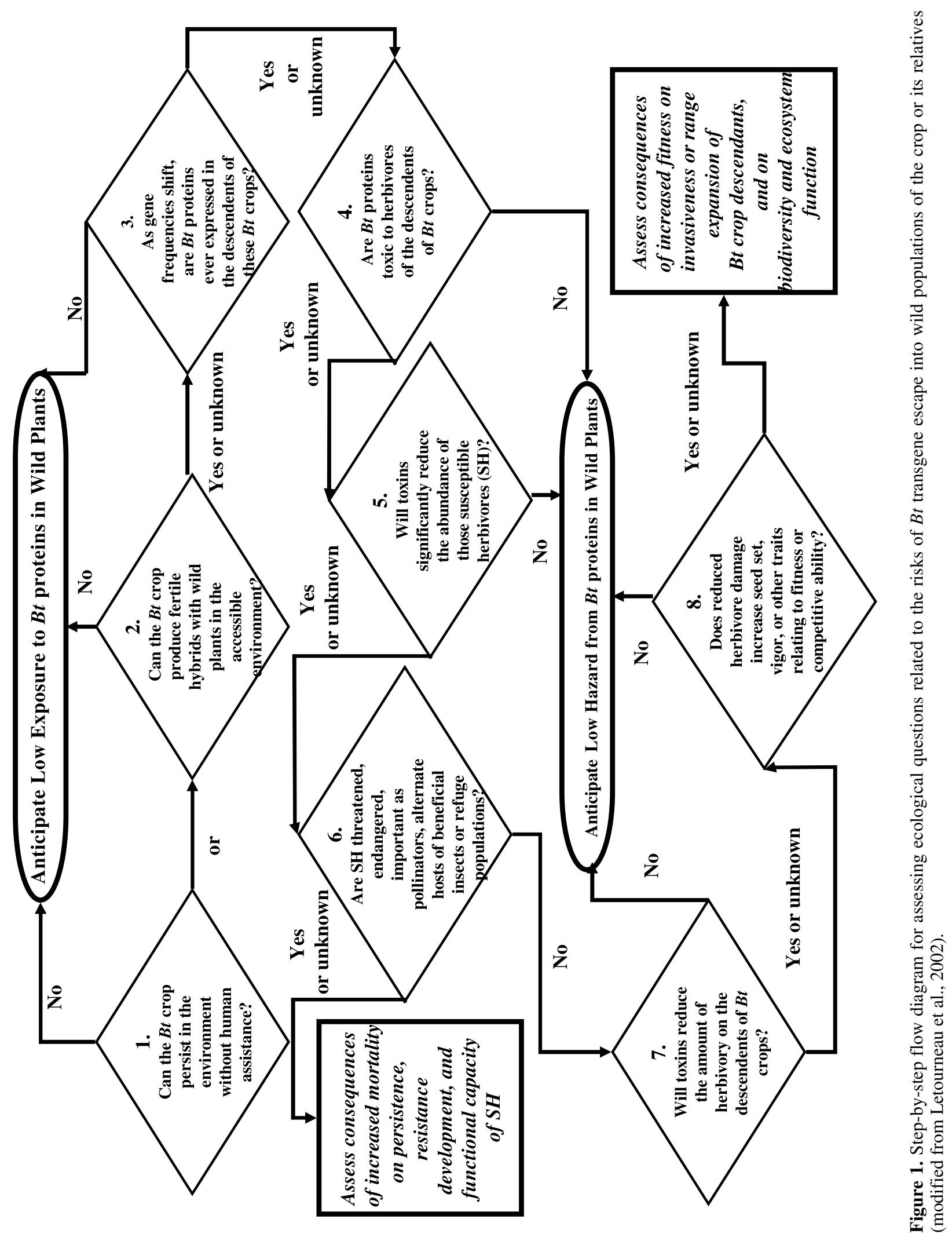


Table 1. Wild relatives of selected $B t$ crops. Sexual compatibility was determined by forced pollinations unless otherwise noted.

\begin{tabular}{|c|c|}
\hline $\begin{array}{l}\text { Brassica napus (rapeseed, canola) } \\
\text { Brassica rapa } \text { (previously B. campestris) }^{3,6} \\
\text { Brassica nigra }^{4} \\
\text { Brassica juncea }^{2,6} \\
\text { Raphanus raphanistrum }^{2} \\
\text { Raphanus sativus }^{2} \\
\text { Brassica oleracea }^{9,10} \\
\text { Sinapis arvensis } \text { (prev. Brassica kaber) }^{8} \\
\text { Hirschfeldia incana } \\
\text { Cakile edentula }^{7} \\
\text { Cakile maritima }^{7} \\
\text { Cardamine californica }^{7}\end{array}$ & $\begin{array}{l}\text { Oryza sativa (rice) } \\
\text { Oryza sativa and Oryza nivara* } \\
\text { (wild red rice) }^{1,3,5,6} \\
\text { Oryza rufipogon } \\
\text { Oryza longistaminata } \\
\text { Oryza glaberrima } 4^{4} \\
\text { Oryza barthii }\end{array}$ \\
\hline $\begin{array}{l}\text { Brassica oleracea (broccoli, cabbage, } \\
\text { cauliflower, brussels sprouts, collards, } \\
\text { etc.) } \\
\text { Brassica napus }{ }^{2} \\
\text { Brassica rapa } 9,10\end{array}$ & $\begin{array}{l}\text { Gossypium hirsutum } \\
\text { (cotton) } \\
\text { Gossypium barbadense }^{1,2} \\
\text { Gossypium tomentosum }^{2} \\
\text { Gossypium barbadense darwinii }^{7} \\
\text { Gossypium mustelinum }^{7}\end{array}$ \\
\hline
\end{tabular}

${ }^{1}$ Cross-compatible; ${ }^{2}$ fertile hybrids obtained; ${ }^{3}$ high rates of hybridization reported; ${ }^{4}$ low rates of hybridization reported, high sterility of hybrids; ${ }^{5}$ USA Federal Noxious Weed List; ${ }^{6}$ hybrids occur naturally in the field; ${ }^{7}$ never tested for hybridization with crop; ${ }^{8}$ no hybrids obtained (Bing, 1991); ${ }^{9}$ ancestral crosses but no evidence of recent hybridization; ${ }^{10}$ gene transfer via "bridging" only; whereas no hybrids between this relative and the crop are expected, gene transfer from the crop to this wild relative could occur via another wild relative which is interfertile with the crop and with this relative.

step-by-step assessment. This assessment differs from some regulatory practices in risk assessment in that it lays the burden of evidence on biosafety rather than on proving harm. To examine the questions posed in Figure 1 for $B t$ rice, $B t$ cotton, and $B t$ rapeseed we queried databases and synthesized data from published studies. These crops represent three distinct plant families grown presently as non-transformed cultivars in many countries of the world, and as transgenic cultivars in the case of cotton. Although we focus on lepidopteran-resistant $B t$ crops, we suggest that many of the questions and data we present could be adapted readily to assessments of $B t$ crops resistant to Coleoptera, Diptera or a broader range of pest taxa.

\section{Potential for gene flow between $B t$ crops and wild relatives}

All commercialized Bt crops either exist in the wild themselves or hybridize with wild relatives somewhere in their range (Ellstrand et al., 1999; Snow and Palma, 1997). For hybridization to occur, the plants must be close enough to each other, in both space and phenological time, for pollen or pollen vectors to move between flowering plants (Ellstrand et al., 1999). The compilation of a comprehensive list of plant species potentially able to produce fertile hybrids with $B t$ crop plants constitutes the first step in determining the potential exposure of the transgene in an assessment of risk associated with gene flow (Fig. 1, questions 1 and 2) (Neeser, 1999; NRC, 2000). For the purpose of this study, we have constructed a list of wild relatives of rapeseed, cotton and rice (Tab. 1), which, though not comprehensive, includes those species that are known to produce fertile offspring as well as a subset of other related plant species. This subset of other plants represents species that are potentially wild relatives of interest due to phylogenetic proximity, but for which little or nothing is known about their actual potential for producing fertile hybrids with related $B t$ crops. That is, neither barriers to successful hybridization nor results of experimental attempts have been documented. The inclusion of such examples of wild relatives for which there is little information is based on two known phenomena: (1) rare events of successful hybridization that may not be discovered without active experimentation and (2) the production of fertile hybrids through intermediate bridging.

Bridging is an avenue for transgene movement from a crop into a wild plant population, even when the wild 
plant species is sexually incompatible with the transgenic crop. For example, Brassica oleracea (cole crops such as broccoli, cabbage, and kale, CC $2 n=18$ ) is not known to cross with its various related weed species, including B. rapa (field mustard, AA $2 \mathrm{n}=20$ ). However, B. oleracea can form a fertile hybrid with Brassica napus (rapeseed, AACC $2 \mathrm{n}=38$ ) (Tab. 1). Those resulting hybrids can then cross with $B$. rapa, an important and widespread weed (Hauser et al., 1998; Jørgensen et al., 1996; Snow et al., 1999). Indeed, B. napus evolved from ancestral, natural crosses between the diploid species $B$. oleracea and B. rapa. Therefore, we include $B$. oleracea (genetically engineered broccoli or cabbage) and $B$. rapa as possible interbreeding species even though fertile hybrids between these species have not been produced in recent times (U, 1935). Because of existing knowledge gaps for some crops, lists of their potential recipient species can be expanded or contracted according to different baseline assumptions.

The evidence supporting decisions on whether or not a particular plant species is considered a possible source of spontaneous crop-wild hybrids should be provided as a transparent part of the environmental assessment process. If the production of fertile crop-wild hybrids is possible, but expected to be an extremely rare occurrence, it can be viewed in two ways: (1) as an acceptably low risk or (2) as an eventual certainty that will occur given enough time and space. We suggest that even the former viewpoint should not be a reason to dismiss further consideration of the consequences of gene flow. Any possibility, however remote, of transgene introgression into wild populations, should be accompanied by an evaluation of its possible consequences (Fig. 1).

\section{Consequences of transgene expression in wild relatives of crops}

Hazards associated with the movement of $B t$ transgenes to wild relatives of $B t$ crops could include increased weediness of the wild relatives; however, population decline of the wild relative is also conceivable should the transgene be detrimental in some way (Bergelson and Purrington, 2002; Elstrand et al., 1999). Other potential hazards include detrimental effects on non-target organisms if the proteins are expressed sufficiently and if these species are sufficiently challenged by the toxic proteins (Fig. 1, questions 3 and 4). We emphasize in our discussion effects on susceptible lepidopterans feeding on wild plant recipients of $B t$ transgenes. However, a wider range of organisms will be exposed to $B t$ proteins that persist in the soil, pollen, and herbivores of these plants (Fig. 1, questions 4-6). The detrimental consequences of mortality in endangered species are obvious, but even when non-target moths or butterflies are harmed, unwanted indirect effects may occur (such as lower pollination rates of a rare plant or reduction of alternate hosts for natural enemies). To assess potential hazards of $B t$ toxin in the tissues of wild relatives, a reasonable starting point is an accurate list of the herbivore species that might be exposed to these toxins (Fig. 1, questions 4-6). We queried The Natural History Museum's HOSTS database to create lists of Lepidoptera known to feed on plants in our sample list of $B t$ crops and wild relatives.

The Natural History Museum's HOSTS database (described by Robinson, 1999) is a compilation of, currently, 175000 host plant records of the world's Lepidoptera drawn from more than 1600 published, manuscript and electronic sources. An abbreviated version is available online: http://www.nhm.ac.uk/ entomology/hostplants/, and published compilations of HOSTS data are available for the "Oriental" region (Robinson et al., 2001) and North America (Robinson et al., 2002a, 2002b).

Although extensive, and perhaps surprisingly diverse, Appendix 1 does not list all of the lepidopteran species that may be of interest as non-target herbivores on our sample of $B t$ crops and wild relatives. HOSTS contains information culled from both the economic and nonapplied entomological literatures, but records at least one host plant for only $19 \%$ of the world's described species of Lepidoptera. Thus, it provides a broad and credible coverage not available from any other source, yet it is still not comprehensive for listing all of the lepidopteran species that could be affected by escaped transgenes.

These difficulties in knowing the potential breadth of exposure to $B t$ crop toxins, even for a relatively wellknown order of insects, create a level of uncertainty for detailed risk assessment. Some groups will be underrepresented because knowledge of different groups of Lepidoptera and richness of different categories of data vary widely (Beccaloni, unpubl.). For example, the database includes host plants for $42 \%$ of $~ 875$ species of Nepticuloidea, and for $69 \%$ of 2000 species of Gracillarioidea because these groups are often collected by rearing. In contrast, host plants for only $9 \%$ of the 21900 Geometroidea and $13 \%$ of the 15900 Pyraloidea are known. These problems may be even more pronounced for microlepidopteran species.

Some plants (including some $B t$ crop relatives) and geographic regions (accessible environments for $B t$ crops and transgenes) are expected to be under-reported. For HOSTS, abstracting of literature has been extensive and 
D.K. Letourneau et al.

Table 2. Total number of Lepidoptera species (subspecific categories pooled) with larvae recorded as feeding upon $B t$ modified or closely related plants. Data from The Natural History Museum's HOSTS database (see Robinson, 1999).

\begin{tabular}{|c|c|c|}
\hline \multirow[t]{19}{*}{ Cruciferae } & Brassica juncea & 25 \\
\hline & Brassica napus & 26 \\
\hline & Brassica nigra & 28 \\
\hline & Brassica oleracea & 123 \\
\hline & Brassica oleracea acephala & 4 \\
\hline & Brassica oleracea botrytis & 15 \\
\hline & Brassica oleracea bullata & 7 \\
\hline & Brassica oleracea capitata & 58 \\
\hline & Brassica oleracea gemmifera & 7 \\
\hline & Brassica oleracea gongylodes & 2 \\
\hline & Brassica oleracea italica & 4 \\
\hline & Brassica rapa & 52 \\
\hline & Cakile edentula & 4 \\
\hline & Cakile maritima & 7 \\
\hline & Cardamine californica & 2 \\
\hline & Hirschfeldia incana & 9 \\
\hline & Raphanus raphanistrum & 9 \\
\hline & Raphanus sativus & 49 \\
\hline & Sinapis arvensis & 6 \\
\hline \multirow[t]{6}{*}{ Gramineae } & Oryza barthii & 0 \\
\hline & Oryza glaberrima & 2 \\
\hline & Oryza longistaminata & 0 \\
\hline & Oryza nivara & 0 \\
\hline & Oryza rufipogon & 0 \\
\hline & Oryza sativa & 292 \\
\hline \multirow[t]{5}{*}{ Malvaceae } & Gossypium barbadense & 31 \\
\hline & Gossypium barbadense darwinii & 0 \\
\hline & Gossypium hirsutum & 22 \\
\hline & Gossypium mustelinum & 0 \\
\hline & Gossypium tomentosum & 2 \\
\hline
\end{tabular}

approaches practical limits for the "Oriental" region, North America, Western Europe and the Afrotropical region, whereas coverage of Central and South America, Asia excluding Western Europe, and Australasia is less comprehensive. Disproportionately fewer host records have been recorded from wild plants than from crop plants because crop pests are preferentially studied. Also, it is rare to find host plant records that cite the subspecies or variety of the plant, which makes it particularly difficult to retrieve records for, say, Brassica oleracea gongylodes in contrast to Brassica oleracea. In addition, misidentification, synonymy, and other potential sources of error are manifold and parallel those encountered in records of host-parasite relationships (Fitton et al., 1988).

Appendix 1 lists 502 lepidopteran species recorded as feeding on cotton, cole crops, rice and their wild relatives, together with a measure of their reported host plant range and geographical distribution. The total number of species recorded as feeding on each of the host plants queried varies from 0 to 292 (Tab. 2). To our knowledge, no such inventory of the herbivores on these plants has 
been published previously, making it difficult even to conceive of the number of non-target lepidopterans potentially to be exposed to $B t$ toxins in the crops and in their wild relatives if the trait were to be transferred.

To approach the question of hazards to lepidopterans, further searches were made of HOSTS to determine how many of these lepidopteran species are potentially dependent upon only one of these hostplants for their survival (Tab. 3). Despite inherent limitations (see Letourneau et al., 2002), HOSTS can provide initial lists of Lepidoptera and some estimate of how dependent these herbivores are on the host plant in question. We consider all the Brassica species listed to be fairly well studied because they are crop-plants. Of the 180 Lepidoptera species recorded from these plants, $41 \%$ occur on more than one Brassica species (Tab. 4). Among those species with multiple hosts, most combinations are represented, suggesting that, to a caterpillar, one Brassica is much the same as another. Of the 10 species listed as feeding on Cakile, $60 \%$ feed also on other genera of Brassicaceae. For Cardamine, Hirschfeldia, Raphanus and Sinapis, 100, 67, 81 and 67\% respectively of their herbivores feed also on other crucifer genera and their diet range always includes at least one Brassica crop species.

In the Poaceae (Tab. 5), three of four species recorded from non-crop plants feed also on the related crop plant. Of 44 species feeding on Gossypium (Tab. 6), $43 \%$ of the 23 species that feed on its non-economic relatives feed also on $G$. barbadense. From the limited records available we may speculate that $40-100 \%$ of the herbivores recorded from the non-economic relatives of crop plants feed also on the crop plant species. The inference seems fair that a similar proportion of the species feeding on the crop plant might feed on the noncrop relatives as well (given geographic feasibility), but sufficient data simply have not been recorded.

The potential transfer of transgenic insecticidal traits to close relatives of crop plants may have implications for biodiversity (Fig. 1, questions 5 and 6). This is especially true for crops with very high acreages of $B t$ varieties because of the spatial exclusion and swamping of edible host plants with palatable, but continuously toxic ones. Moths and butterflies that are host-specific, and whose host plants inherit the ability to produce lethal toxins, will experience local extinctions (or become resistant). Under-recording no doubt inflates artificially the impression of widespread monophagy within the Lepidoptera (Letourneau et al., 2002). However, of 18503 Lepidoptera species for which we have at least one host plant record, almost half (9062) are recorded from just a single host plant species (Robinson, 1998). In Table 3 we list Lepidoptera taxa that are recorded as feeding only on the crop-plant (or near-relative) genera and which are endemic to the same geographical region as that in which the crop plant (and its putative progenitors) originated. For the plant genera dealt with here, 80 Lepidoptera species appear to have a host range that is restricted to that genus. If locally available hosts were to obtain the insect-resistance trait, there could be several types of consequences, from the extirpation of these potentially hostspecific, non-target lepidopteran species to the hastened development of resistance in crop pests. The spread of an insect-resistance trait in formerly susceptible wild relatives of crop plants would eliminate a natural "refuge" that serves to maintain susceptible pest lepidopterans in the target population (Alstad and Andow, 1995; Andow, 2002).

\section{Susceptibility of lepidopteran species to $B t$ toxins}

One general protocol for assessing the effects of a transgene coding for $B t$ proteins in a wild relative of a crop plant would be to determine directly if any of the herbivores that feed on that plant are susceptible to the toxin (produced in response to the cry gene in question). If the herbivores are not susceptible to the $B t$ proteins, then neither the transgenic offspring nor the herbivore is likely to experience population level changes due to the insect resistance trait per se, and risk assessment research efforts might be directed elsewhere (Fig. 1, questions 4, 5 and 7). Typically, research efforts have emphasized testing of major target pests or a known susceptible insect rather than a range of lepidopterans that occur either on target host plants or in geographic areas of toxin introduction. We are aware of no systematic measurement of mortality rates for the hundreds of lepidopterans recorded as feeding on $B t$ crops and their relatives.

To determine which of the species recorded in Appendix 1 are susceptible to $B t$ endotoxins, we consulted a comprehensive database of published toxicity studies for $B t$ maintained by the Canadian Forest Service (van Frankenhuyzen K. and Nystrom C., "The Bacillus thuringiensis toxin specificity database", (1999), http:// www.glfc.cfs.nrcan.gc.ca/bacillus). As of January 2001, approximately $3 \%$ of the 502 lepidopterans known to use rapeseed, cotton, rice, and wild relatives of these $B t$ crops had been tested for $B t$ susceptibility (commercially available proteins) as documented in published studies. Specifically, of all the lepidopteran species listed in Appendix 1 , susceptibility data are available on the following 
D.K. Letourneau et al.

Table 3. Lepidoptera species (subspecific categories pooled) with a recorded host range of only one plant genus within which $B t$ manipulation has occurred and which are potentially at risk of extirpation if no alternative host exists.

\begin{tabular}{|c|c|c|c|}
\hline \multirow[t]{6}{*}{ Arctiidae $^{1}$} & Amata huebneri Boisduval & or & Oryza \\
\hline & Creatonotos punctivitta Walker & af & Oryza \\
\hline & Estigmene senegalensis Rothschild & af & Oryza \\
\hline & Schistophleps bipuncta Hampson & or & Oryza \\
\hline & Spilosoma scortilla Wallengren & af & Oryza \\
\hline & Thumatha fuscescens Walker & or & Oryza \\
\hline \multirow[t]{3}{*}{ Gelechiidae } & Athrips studiosa Meyrick & or & Oryza \\
\hline & Helcystogramma nr. malacogramma Meyrick & af & Oryza \\
\hline & Pityocona xeropis Meyrick & or & Oryza \\
\hline Geometridae & Pamphlebia rubrolimbraria Guenée & or & Oryza \\
\hline Gracillariidae & Phyllonorycter triarcha Meyrick & af; or & Gossypium \\
\hline \multirow[t]{5}{*}{ Hesperiidae } & Ampittia dioscorides Fabricius & or & Oryza \\
\hline & Baoris pagana de Nicéville & or & Oryza \\
\hline & Parnara poutieri Boisduval & af & Oryza \\
\hline & Potanthus tropica Plötz & or & Oryza \\
\hline & Prosopalpus styla Evans & af & Oryza \\
\hline \multirow[t]{2}{*}{ Lymantriidae } & Laelia fasciata Moore & or & Oryza \\
\hline & Laelia rosea Schaus \& Clement & af & Oryza \\
\hline \multirow[t]{16}{*}{ Noctuidae } & Aletia panarista Fletcher & af & Oryza \\
\hline & Aletia umbrigera Saalmüller & af & Oryza \\
\hline & Anomis luridula Guenée & nt & Gossypium \\
\hline & Gnamptonyx innexa Walker & af & Oryza \\
\hline & Hiccoda nigripalpis Walker & or & Oryza \\
\hline & Leucania albistigma Moore & or & Oryza \\
\hline & Leucania compta Moore & or & Oryza \\
\hline & Leucania roseilinea Walker & or & Oryza \\
\hline & Maliattha signifera Walker & or & Oryza \\
\hline & Rhododactyla elicrina Felder & af & Oryza \\
\hline & Rivula atimeta Swinhoe & or & Oryza \\
\hline & Rivula continentalis Gaede & af & Oryza \\
\hline & Rivula innotabilis Swinhoe & or & Oryza \\
\hline & Sesamia venosata Moore & or & Oryza \\
\hline & Spodoptera pulchella Herrich-Schäffer & nt & Gossypium \\
\hline & Trichoplusia indicator Walker & af & Oryza \\
\hline \multirow[t]{3}{*}{ Nymphalidae } & Bicyclus dorothea Cramer & af & Oryza \\
\hline & Bicyclus vulgaris Butler & af & Oryza \\
\hline & Mycalesis mamerta Stoll & or & Oryza \\
\hline
\end{tabular}


Assessing environmental consequences of transgene escape

Table 3. Continued.

\begin{tabular}{|c|c|c|c|}
\hline & Mycalesis nr. lorna Grose-Smith & $\mathrm{au}$ & Oryza \\
\hline & Mycalesis visala Moore & or & Oryza \\
\hline Pieridae & Zegris eupheme Esper & $\mathrm{pl}$ & Hirschfeldia \\
\hline \multirow[t]{19}{*}{ Pyralidae } & Adelpherupa flavescens Hampson & af & Oryza \\
\hline & Ancylolomia japonica Zeller & ow & Oryza \\
\hline & Ancylosis convexella Lederer & af & Oryza \\
\hline & Bleszynskia malacelloides Bleszynski & or & Oryza \\
\hline & Catagela adjurella Walker & or & Oryza \\
\hline & Chilo aleniella Strand & af & Oryza \\
\hline & Chilo nr. partellus Swinhoe & or & Oryza \\
\hline & Cnaphalocrocis bilinealis Hampson & or & Oryza \\
\hline & Endotricha melanobasis Hampson & or & Oryza \\
\hline & Epina dichromella Walker & or & Oryza \\
\hline & Mabra eryxalis Walker & or & Oryza \\
\hline & Marasmia ruralis Walker & or & Oryza \\
\hline & Metoeca foedalis Guenée & or & Oryza \\
\hline & Panalipa immeritalis Walsingham & or & Oryza \\
\hline & Parerupa africana Aurivillius & af & Oryza \\
\hline & Scirpophaga gilviberbis Zeller & af; or & Oryza \\
\hline & Scirpophaga melanoclista Meyrick & af & Oryza \\
\hline & Scirpophaga subumbrosa Meyrick & af & Oryza \\
\hline & Zovax vangoghi Bleszynski & af & Oryza \\
\hline Thyrididae & Opula spilotata Warren & af & Oryza \\
\hline
\end{tabular}

\footnotetext{
${ }^{1}$ Species feeding only on a $B t$ manipulated plant genus but with a distribution outside the original distribution of the crop species and its close allies/progenitors are excluded on the grounds that they must have alternative hosts. Data from The Natural History Museum's HOSTS database (see Robinson, 1999). Distribution is indicated by a two-letter code, thus: af = Afrotropical region; $\mathrm{au}=$ Australasia; $\mathrm{na}=$ Nearctic region; $\mathrm{nt}=$ Neotropical region; or $=$ Oriental region; ow $=$ Old World $; \mathrm{pl}=$ Palaearctic region .
}

species: Actebia fennica, Agrotis ipsilon, Chilo suppressalis, Elasmolpalpus lignosellus, Heliocoverpa zea, H. armigera, Heliothis virescens, Manduca sexta, Mamestra brassicae, Mamestra configurata, Pieris rapae, Plutella xylostella, Plodia interpunctella, Spodoptera frugiperda, and Trichoplusia ni. Susceptibility levels for most non-target species are not available, either because no tests have been conducted or because test data on proprietary (especially genetically modified) proteins are confidential business information (Letourneau et al., 2002; van Frankenhuyzen and Nystrom, 1999).

Even limited data on the susceptibility of target pests to $B t$ crop toxins could be helpful if the pests represent a range of lepidopteran families, and if extrapolation to non-target species in the same taxonomic group is reasonably accurate. The available data on susceptibility levels among species, however, suggest that these traits do not fall cleanly along broad taxonomic lines, such as suborders or families or even genera. For the lepidopteran pests examined, variability in susceptibility exists among closely related taxa, among different instars (or sizes) of the same species, and depends upon the particular protein being expressed by the plant, transgenic event, and the crop line, which can determine both the level of Cry protein expression and what plant tissues express the trait (Acciarri et al., 2000; Archer et al., 2000; Ashfaq et al., 2000; Macintosh et al., 1990; van Frankenhuyzen et al., 1991). 
D.K. Letourneau et al.

Table 4. Number of Lepidoptera species feeding on the indicated hostplant or hostplants shows the pattern and frequency of shared hostplants in Brassicaceae (species listed in and abbreviated from Appendix 1) among 199 Lepidoptera species (subspecific taxa not differentiated); 126 species are recorded from a single hostplant from within this group.

\begin{tabular}{|c|c|c|c|c|c|c|c|c|c|c|c|c|}
\hline 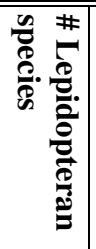 & 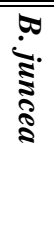 & 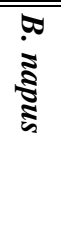 & 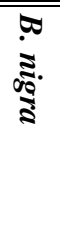 & 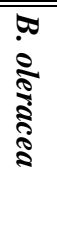 & 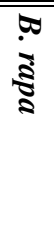 & 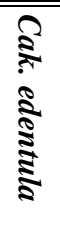 & 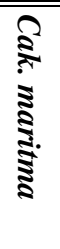 & 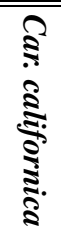 & 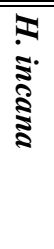 & 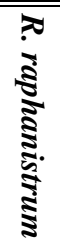 & 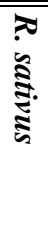 & 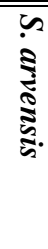 \\
\hline $\mathbf{1}$ & & & & & & & & & & & & \\
\hline 2 & & & & & & & & & & & & \\
\hline 1 & & & & & & & & & & & & \\
\hline 1 & & & & & & & & & & & & \\
\hline 4 & & & & & & & & & & & & \\
\hline 1 & & & & & & & & & & & & \\
\hline 3 & & & & & & & & & & & & \\
\hline 4 & & & & & & & & & & & & \\
\hline 1 & & & & & & & & & & & & \\
\hline 7 & & & & & & & & & & & & \\
\hline 1 & & & & & & & & & & & & \\
\hline 1 & & & & & & & & & & & & \\
\hline 1 & & & & & & & & & & & & \\
\hline $\mathbf{1}$ & & & & & & & & & & & & \\
\hline 5 & & & & & & & & & & & & \\
\hline 4 & & & & & & & & & & & & \\
\hline 1 & & & & & & & & & & & & \\
\hline 3 & & & & & & & & & & & & \\
\hline 1 & & & & & & & & & & & & \\
\hline 1 & & & & & & & & & & & & \\
\hline 2 & & & & & & & & & & & & \\
\hline 1 & & & & & & & & & & & & \\
\hline 1 & & & & & & & & & & & & \\
\hline 2 & & & & & & & & & & & & \\
\hline 1 & & & & & & & & & & & & \\
\hline 1 & & & & & & & & & & & & \\
\hline 3 & & & & & & & & & & & & \\
\hline 2 & & & & & & & & & & & & \\
\hline 6 & & & & & & & & & & & & \\
\hline 1 & & & & & & & & & & & & \\
\hline 1 & & & & & & & & & & & & \\
\hline
\end{tabular}


Table 4. Continued.

\begin{tabular}{|c|c|c|c|c|c|c|c|c|c|c|c|c|}
\hline 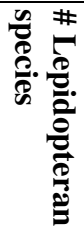 & 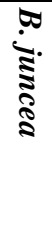 & 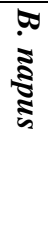 & 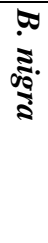 & 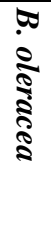 & $\begin{array}{l}\square \\
\vdots \\
\vdots \\
\vdots\end{array}$ & 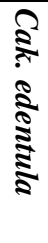 & 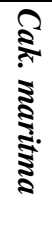 & 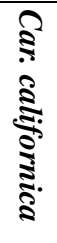 & 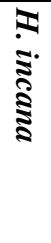 & 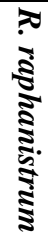 & 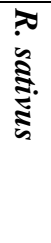 & 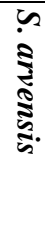 \\
\hline 13 & & & & & & & & & & & & \\
\hline 1 & & & & & & & & & & & & \\
\hline 7 & & & & & & & & & & & & \\
\hline 86 & & & & & & & & & & & & \\
\hline 2 & & & & & & & & & & & & \\
\hline 6 & & & & & & & & & & & & \\
\hline 1 & & & & & & & & & & & & \\
\hline 3 & & & & & & & & & & & & \\
\hline 3 & & & & & & & & & & & & \\
\hline 1 & & & & & & & & & & & & \\
\hline 9 & & & & & & & & & & & & \\
\hline 2 & & & & & & & & & & & & \\
\hline
\end{tabular}

Table 5. Number of Lepidoptera species feeding on the indicated hostplant or hostplants shows the pattern and frequency of shared hostplants in Poaceae (species listed in and abbreviated from Appendix 1) among 571 Lepidoptera species (subspecific taxa not differentiated); 472 species are recorded from a single hostplant from within this group.

\begin{tabular}{c|c|c|c|c}
\hline $\begin{array}{c}\text { \# Lepidopteran } \\
\text { species }\end{array}$ & O. glaberrima & O. sativa & Z. mays & Z. mexicana \\
\hline 278 & & & & \\
\hline 193 & & & & \\
\hline 96 & & & & \\
\hline 2 & & & & \\
\hline 1 & & & & \\
\hline 1 & & & & \\
\hline
\end{tabular}

Table 6. Number of Lepidoptera species feeding on the indicated hostplant or hostplants shows the pattern and frequency of shared hostplants in Malvaceae (Gossypium) (species listed in and abbreviated from Appendix 1) among 44 Lepidoptera species (subspecific taxa not differentiated); 34 species are recorded from a single hostplant from within this group.

\begin{tabular}{c|c|c|c}
\hline $\begin{array}{c}\text { \# Lepidopteran } \\
\text { species }\end{array}$ & G. barbadense & G. hirsutum & G. tomentosa \\
\hline 1 & & & \\
\hline 12 & & & \\
\hline 21 & & & \\
\hline 9 & & & \\
\hline 1 & & & \\
\hline
\end{tabular}


According to available data, non-target lepidopterans also vary greatly in their susceptibility to $B t$ sprays (e.g. Johnson et al., 1995; Wagner et al., 1996). Bt sprays were toxic to cinnabar moth larvae Tyria jacobaea (L.) only when they were exposed to the toxins in later instars (James et al., 1993). Peacock et al. (1998) showed that 27 of 42 species of forest Lepidoptera tested suffered mortality from $B t$ var. kurstaki sprays, especially when treated as early instars. Both susceptible and non-susceptible larvae were found in most of the seven families tested (Papilionidae, Nymphalidae, Geometridae, Lasiocampidae, Saturniidae, and Noctuidae). For example, species were found in both Geometridae and Noctuidae whose larvae, when exposed to $B t$ sprays, had no mortality or experienced $100 \%$ mortality.

This variability in susceptibility may extend to the population level. As has been documented by Bourguet et al. (2000) for the European Corn Borer, if the population genetics of pest species is such that some isolation exists between individuals exploiting crop plants and those in the same species feeding on non-crop hosts, then extrapolation from the little we do know about pest susceptibility to $B t$ crops may be misleading. As a further complication in terms of predicting susceptibility levels of non-target Lepidoptera, we expect there to be interactions between effects of secondary plant compounds in the host plant and the results of exposure to $B t$ proteins (e.g. Navon, 1993; Krishik et al., 1988; discussed such interactions between plant compounds and $B t$ toxins in spray formulations). Some substances, such as L-canavanine and tannin, were shown to enhance the toxicity of Bt proteins (Felton and Dahlman, 1984; Schuster and Calderone, 1986). In other cases, the delivery of toxic protein via plant tissues will increase the mortality rate for herbivores compared to that experienced when anti-bacterial secondary compounds fed upon by the herbivore inhibit toxin production in the gut (Reichelderfer, 1991). Hedin et al. (1978) found that cotton extracts suppressed the growth of B. thuringiensis.

Inspired by the findings of Losey and colleagues (Losey et al., 1999, 2002) that monarch butterflies suffer mortality when larvae fed on event $176 \mathrm{Bt}$ corn pollen, some susceptibility data for non-target lepidopterans to $B t$ toxins expressed in plant tissue are accumulating (Jesse and Obrycki, 2000; Hellmich 2001; Sears et al., 2001; Zangerl et al., 2001). However, the susceptibility of most caterpillars that act as significant herbivores of $B t$ crops or the wild relatives of $B t$ crops remains unknown and substantially unpredictable.

\section{Fitness and other effects of lepidopterans on wild plants}

Lepidoptera are the primary defoliators in agroecosystems (Barbosa, 1993), and certainly damage marketable products in agriculture. But are caterpillars a good candidate for controlling populations of wild plants (Fig. 1, question 8)? Perhaps data from programs on biological control of weeds, where wild plant populations have indeed been regulated and maintained at low densities by herbivores, provide the strongest evidence that herbivores play a critical role in reducing wild plant fitness and invasiveness (e.g. Story et al., 2000; Volenberg et al., 1999). Of course, these herbivores are selected specifically to control plants, and include some "alien" introductions uncontrolled by an endemic enemy loading. So these may, in aggregate, effect greater levels of weed control than would be expected for the suite of lepidopterans that could be excluded from $B t$ crops and resistant wild relatives. However, selection criteria for herbivores for biological weed control agents could perhaps play a part in predicting which are the key herbivores of interest in risk assessment.

A rich body of knowledge is certainly developing as critical control points in the life cycle of weeds (e.g. juvenile survival, seed development, or overwinter survival) are identified as strong determining factors in the population dynamics of the plant (Doak, 1992; Parker, 2000; Shea and Kelly, 1998). In some weed species, seedlings and juveniles appear to be the most susceptible life stages. Individuals at these stages are relatively easy to kill, and significant reductions in their numbers will reduce the overall weed status of the plant (Kriticos et al., 1999). If, on the other hand, these same controls were already functioning in a natural population of wild plants, removal of the controlling factors through plant resistance would release the plant, resulting in higher population densities and/or changes in invasiveness. Therefore, researchers must pay attention to whether or not the lepidopteran herbivores affected by $B t$ based resistance are indeed those species that attack the plant at control points in the life cycle - if, indeed, control points in the wild species of interest are known.

Lepidopterans do meet one important criterion for host plant regulation; they can reduce plant fitness (e.g. Agrawal, 1999; Koptur, 1990; Maron, 1998; Marquis, 1992, 1984; Paulissen, 1987; Pilson, 2000; Strauss et al., 1999). Caterpillar defoliation, root damage or vascular tissue damage sometimes work in concert with other stress factors such as plant-plant competition or herbivory by other arthropods (James et al., 1993; Juenger and 
Bergelson, 1998). Specific research on the effects of $B t$ based resistance in wild Brassica populations has demonstrated effects of herbivory on plant fitness, especially when other stresses, such as poor soil quality and interspecific plant competition, are present (Bergelson, 1994; Meyer, 2000). Stewart et al. (1997) showed that transgenic, insect-resistant B. napus showed lower levels of defoliation, decreased mortality, and higher seed output compared to non-transgenic plants when grown in cultivated plots. Snow et al. (2003) demonstrated strong fecundity benefits of a single $B t$ transgene conferring insect-resistance in wild sunflowers. Population level impacts of changes in individual plant fitness (such as increased invasiveness or range expansion) can be predicted using demographic models with data collected from small-scale field experiments (Caswell, 2001; Kareiva et al., 1996; Marvier and Kareiva, 1999; Snow et al., 2003).

Caterpillars can also have indirect effects on wild plants in their habitats that may be relevant to risk assessments. Feeding by caterpillars can induce plant resistance against other herbivores (Agrawal, 1999; Agrawal et al., 1999) and/or can increase specific volatiles, which act as attractants for parasitoids and predators of the herbivore in question (e.g. Geervliet et al., 1997; McCall et al., 1994; Turlings et al., 1998). Caterpillar feeding can even cause unpredicted, negative effects on other plant species of interest in the same habitat. For example, Callaway et al. (1999) showed how a biological control agent (knapweed root moth) introduced to reduce the invasiveness of a weed and encourage the growth of native species actually caused a reduction in the native plant's fitness via root exudate mediated effects triggered by the lepidopteran. Damage from caterpillars can also serve as a potential selective factor in the evolution of flowering phenology (Pilson, 2000), determine the level of fitness depression caused by unrelated insects (Juenger and Bergelson, 1998; Naber and Aarssen, 1998; Pilson, 1996), reduce pollinator visitation (Strauss et al., 1999), variably affect plant fitness depending upon the timing or pattern of damage (Marquis, 1992; Mauricio et al., 1993), and cause increased biodiversity in the endophagous herbivore community (Tscharntke, 1999).

Clearly, many factors interact to determine the success of a novel plant at a given site and time of introduction, including abiotic factors and the abundance and identities of mutualists, competitors, herbivores, etc. (Crawley et al., 1996). As more traits are added to crop plants, risk assessment of the consequences of gene flow will be more complex. However, predicting the potential for weediness and invasiveness of plant species in different habitats is extremely important given the fact that invasions can lead to a reduction in biological diversity and threaten ecosystem integrity (Daehler and Strong, 1996).

\section{CONCLUSION}

Hoffman (1990) used the incorporation of $B t$ endotoxins in crop plants as a case study for posing a series of initial questions about possible environmental consequences of transgenic crops. She speculated about plant community effects of increased survival, reproduction or invasiveness of wild crop relatives, the consequences of increased competitive ability on plant biodiversity, and long distance effects of susceptible pollinators whose populations have been reduced by toxic host plants. Over a decade later, we have a greater appreciation for the complexity of insect-plant and plant-plant interactions, but the available data for predicting environmental consequences of transgenic traits remain weak. Despite the expanded cultivation of $B t$ crops in the USA and worldwide, very basic ecological questions remain unanswered, creating a scientific vacuum instead of a scientific foundation for the assessment of environmental effects. The overwhelming conclusion of recent studies is that gene flow will occur if there are wild relatives in the region that can hybridize with the crop (Kareiva et al., 1994; Klinger and Ellstrand, 1994). In the absence of barriers to the incorporation and expression of the trait (and its promoters) over time and expansion of the acreage and distribution of $B t$ crops, cry genes will likely enter wild plant populations. Kareiva et al. (1994) urged that ecologists begin to fill information gaps about the consequences of such gene flow to wild gene pools in order to have the tools to make regulatory decisions and to mitigate harmful consequences. These information gaps include basic answers about the forces that control the distribution, abundance and diversity of wild plant species in terrestrial communities (e.g. Doak, 1991; Letourneau and Dyer, 1999; McNaughton, 1986; Price, 1992). Within this context, we need to understand the influence of $B t$-based toxins on naturally occurring Lepidoptera (Smith and Couche, 1991), and the actual role of lepidopterans as regulating forces for plants in natural and agricultural habitats.

Theoretically, an herbivore resistance trait could indeed increase fitness of weeds in natural populations and its invasiveness in the community. Yet we are faced with scientific controversies about the role of consumer dynamics as forces controlling plant population levels and community structure. To predict the outcome of transgene escape, manipulative experiments become 
necessary but are not available (Fretwell, 1977; Kareiva et al., 1994; Marvier and Kareiva, 1999; McNaughton, 1986; NRC, 2002; Royal Society of Canada, 2000; Strong, 1984, 1992; Turkington et al., 1993). To date, predictions about the behavior of non-target lepidopterans on wild crop relatives must be made in the absence of any comprehensive species list of these herbivores. If none of these species is susceptible to $B t$ based endotoxins, or none is currently regulating populations of their host plant, then increased weediness is not likely (Fig. 1). If susceptible non-target herbivores are not rare and endangered, relied upon as genetic stock in refugia against resistance development, acting as important pollinators in the ecosystem, nor fulfilling any other key function, then the environmental price for transgene transfer from commercialized $B t$ crops to their wild relatives may be insignificant. Unfortunately, the scientific basis for assessing the queries Hoffman (1990) posed over a decade ago remains inadequate, and the challenges for environmental researchers and regulators will only increase as they ponder biosafety issues for multiple, stacked traits in a wider range of plants, in a context of global trade. Attempts at greater transparency in the regulatory decision process will encourage a step-by-step framework for analysis, demonstrate strengths and weakness in the assessments, and aid in identifying critical research areas.

\section{ACKNOWLEDGMENTS}

We are grateful to Pedro Barbosa, Sara Bothwell, Lee Dyer, Norm Ellstrand, Roslyn McKendry, Tom Miller, John Sulzycki, and Fequiere Vilsaint for helpful comments on an earlier version of the manuscript. We thank Carl Nystrom and Kees van Frankenhuyzen for compiling lepidopteran susceptibility test information for the species in question.

Received October 9, 2002; accepted July 29, 2003.

\section{Appendix 1}

The Lepidoptera that feed on $B t$ modified cole crops, cotton, rice or their close relatives

${ }^{1}$ Hostplant specificity is indicated by number of plant families and genera recorded as the food plants of the species, thus "10/24" indicates that ten families and twenty-four genera of plants are recorded as hosts. Where the number of hostplant families exceeds that of the number of genera, excess families are each for a record in which no plant genus is specified. ${ }^{2}$ Distribution is indicated by a two-letter code, thus: af = Afrotropical region; $\mathrm{au}=$ Australasia and Pacific $; \mathrm{cm}=$ cosmopolitan; $\mathrm{hl}=$ Holarctic region (Nearctic + Palearctic); hw = Hawaii; ia = Indo-Australian region (Oriental + Australasia); na $=$ Nearctic region; $n t=$ Neotropical region; $\mathrm{nw}=\mathrm{New}$ World $($ Nearctic + Neotropical regions); $\mathrm{nz}=$ New Zealand; or = Oriental region; ow = Old World; pl = Palaearctic region. Distribution is simplified from individual records and may involve overlap and/or duplication. Data from The Natural History Museum's HOSTS database.

\section{BRASSICACEAE ${ }^{1}$}

\section{Brassica juncea}

Arctiidae: Syntomis sperbius Fabricius [3/4] (or). ${ }^{2}$

Geometridae: Hemithea costipunctata Moore [7/ 10] (or).

Noctuidae: Agrotis ipsilon Hufnagel [30/74] (af; au; cm; hw; ia; na; nt; nz; or; ow; pl); Chrysodeixis eriosoma Doubleday [18/29] (au; ia; or; pl); Spodoptera litura Fabricius [69/166] (af; au; cm; ia; nt; or; ow); Tiracola plagiata Walker [30/54] (au; ia; or); Trichoplusia ni brassicae Riley [1/1] (or); Trichoplusia orichalcea Fabricius [24/57] (af; au; or; ow); Zurobata vacillans Walker [7/8] (au; or).

Pieridae: Appias libythea Fabricius [3/5] (or); Artogeia canidia Linnaeus [2/4] (or); Ascia monuste monuste Linnaeus [4/7] (nt); Hesperocharis marchalii marchali GuérinMéneville [3/4] (nt); Phoebis statira Cramer [2/2] (nt); Pieris brassicae Linnaeus [6/24] (cm; or; pl); Pieris helice johnstoni Crowley [2/3] (af); Pieris rapae Linnaeus [6/31] (au; cm; hw; na; nz; or; pl); Pieris rapae crucivora Boisduval [3/6] (or; ow); Pontia helice Linnaeus [3/9] (af).

Pyralidae: Corcyra cephalonica Stainton [19/39] (af; cm; hw; na; nt; or); Crocidolomia pavonana Fabricius [7/13] (af; au; cm; or; ow); Diaphania indica Saunders [9/19] (af; au; cm; or; pl); Hellula undalis Fabricius [4/11] (af; au; hw; ia; or; ow); Omiodes diemenalis Guenée [6/29] (au; ia; or).

Tortricidae: Adoxophyes privatana Walker [31/ 53] (ia; or; ow; pl).

Yponomeutidae: Plutella xylostella Linnaeus [11/ 22] (af; au; cm; hw; ia; na; nt; or; pl). 


\section{Brassica napus}

Geometridae: Xanthorhoe designata Hufnagel [2/ 6] (na; pl); Xanthorhoe fluctuata Linnaeus [2/7] (pl).

Hepialidae: Hepialus humuli Linnaeus [12/19] (pl); Korscheltellus lupulina Linnaeus [10/18] (pl).

Noctuidae: Autographa gamma Linnaeus [25/75] (cm; na; nt; pl); Discestra trifolii Hufnagel [17/34] (cm; na; or; pl); Euxoa messoria Harris [16/27] (na); Euxoa nigricans Linnaeus [11/12] (hl; pl); Lacinipolia renigera Stephens [12/18] (na; pl); Mamestra brassicae Linnaeus [14/27] (or; pl); Mamestra configurata Walker [16/33] (na; nt); Melanchra picta Harris [26/48] (hl; na); Pseudaletia unipuncta Haworth [18/53] (au; cm; hw; na; nt; or; pl); Spodoptera ornithogalli Guenée [25/53] (cm; na; nt); Trichoplusia ni Hübner [27/ 65] (af; cm; hw; na; nt; or; pl); Trichordestra legitima Grote [11/22] (na).

Pieridae: Anthocharis sara Lucas [1/16] (na); Ascia monuste eubotea Godart [4/7] (nt); Euchloe ausonides Lucas [1/12] (na); Pieris brassicae Linnaeus [6/24] (cm; or; pl); Pieris napi Linnaeus [4/21] (hl; na; or; pl); Pieris rapae Linnaeus [6/31] (au; cm; hw; na; nz; or; pl); Pieris rapae rapae Linnaeus [4/14] (au; cm).

Pyralidae: Hellula phidilealis Walker [3/6] (cm; na; nt); Hellula rogatalis Hulst [2/5] (na).

Sphingidae: Manduca sexta Linnaeus [7/16] (na; nt; nw).

Yponomeutidae: Plutella xylostella Linnaeus [11/ 22] (af; au; cm; hw; ia; na; nt; or; pl).

\section{Brassica nigra}

Arctiidae: Arachnis picta Packard [8/13] (na); Pericallia ricini Fabricius [31/45] (or); Spilosoma obliqua Walker [27/54] (or).

Noctuidae: Agnorisma badinodis Grote [9/11] (na); Agrotis ipsilon Hufnagel [30/74] (af; au; cm; hw; ia; na; nt; nz; or; ow; pl); Agrotis orthogonia Morrison [11/27] (na); Copablepharon viridisparsa Dod [1/2] (na); Euxoa auxiliaris Grote [16/42] (na); Ochropleura flammatra Denis and Schiff. [13/19] (or; ow; pl); Peridroma saucia Hübner [40/86] (cm; na; nt; pl); Spodoptera exigua Hübner [35/83] (af; au; cm; hw; na; or; pl); Spodoptera litura Fabricius [69/166] (af; au; cm; ia; nt; or; ow); Trichoplusia ni Hübner [27/65] (af; cm; hw; na; nt; or; pl).
Pieridae: Anthocharis sara Lucas [1/16] (na); Euchloe ausonides Lucas [1/12] (na); Pieris brassicae Linnaeus [6/24] (cm; or; pl); Pieris napi Linnaeus [4/21] (hl; na; or; pl); Pieris protodice Boisduval and Le Co [1/2] (na); Pieris rapae Linnaeus [6/31] (au; cm; hw; na; nz; or; pl); Pontia beckerii Edwards [2/8] (na); Pontia occidentalis Reakirt [4/18] (na; pl); Pontia protodice Boisduval and LeC. [3/23] (na; nt).

Psychidae: Apterona crenulella helix Siebold [19/ 39] (pl).

Pyralidae: Crocidolomia pavonana Fabricius [7/ 13] (af; au; cm; or; ow); Eustixia pupula Hübner [2/ 3] (na); Hellula undalis Fabricius [4/11] (af; au; hw; ia; or; ow); Plodia interpunctella Hübner [25/ 48] (af; cm; na; nt; or; pl).

Yponomeutidae: Plutella xylostella Linnaeus [11/ 22] (af; au; cm; hw; ia; na; nt; or; pl).

\section{Brassica oleracea}

Arctiidae: Alpenus investigatorum Karsch [15/24] (af; pl); Amsacta lactinea Cramer [26/45] (or); Estigmene acrea Drury [23/46] (na; nt; nw); Hypercompe abdominalis Walker [2/2] (nt); Hypercompe indecisa Walker [13/19] (nt); Hypercompe scribonia Stoll [15/17] (na); Nyctemera baulus Boisduval [3/4] (au; or); Paracles fusca Walker [13/20] (nt); Pericallia ricini Fabricius [31/45] (or); Spilosoma obliqua Walker [27/54] (or); Spilosoma sumatrana Swinhoe [11/15] (or); Spilosoma virginica Fabricius [44/86] (cm; na); Teracotona submacula Walker [4/5] (af).

Cosmopterigidae: Pyroderces badia Hodges [16/ 18] (hw; na).

Geometridae: Eupithecia pulchellata Stephens [2/ 2] (pl); Hemithea costipunctata Moore [7/10] (or); Scopula fibulata Guenée [6/7] (or); Xanthorhoe designata Hufnagel [2/6] (na; pl); Xanthorhoe iduata Guenée [2/2] (na); Xanthorhoe saturata Guenée [4/5] (or; pl).

Limacodidae: Parasa lepida Cramer [35/77] (ia; or; ow).

Lymantriidae: Clethrogyna turbata Butler [20/35] (or); Olene mendosa Hübner [50/97] (af; au; ia; or); Somena scintillans Walker [38/76] (or).

Noctuidae: Abagrotis alternata Grote [8/12] (na); 
Agrotis gladiaria Morrison [11/17] (na); Agrotis infusa Boisduval [7/9] (au); Agrotis ipsilon Hufnagel [30/74] (af; au; cm; hw; ia; na; nt; nz; or; ow; pl); Agrotis malefida Guenée [11/19] (na; nt; nw); Agrotis repleta Walker [11/20] (nt); Agrotis segetum Denis and Schiff. [21/45] (af; or; ow; pl); Agrotis subterranea Fabricius [17/39] (na; nt; nw); Agrotis vetusta Walker [13/20] (na); Anagrapha falcifera Kirby [11/17] (na); Apamea amputatrix Fitch [7/9] (na); Apamea devastator Brace [9/19] (na); Argyrogramma signata Fabricius [7/12] (af; au; or; ow); Autographa californica Speyer [26/44] (na); Autographa gamma Linnaeus [25/75] (cm; na; nt; pl); Autographa precationis Guenée [11/17] (na); Chrysodeixis acuta Walker [18/26] (af; or; ow); Chrysodeixis chalcites Esper [28/75] (af; au; cm; or; ow; pl); Chrysodeixis eriosoma Doubleday [18/29] (au; ia; or; pl); Condica sutor Guenée [3/ 11] (af; na; nt); Discestra trifolii Hufnagel [17/34] (cm; na; or; pl); Ercheia cyllaria Cramer [5/4] (or); Euxoa auxiliaris Grote [16/42] (na); Euxoa infausta Walker [4/6] (na); Euxoa intrita Morrison [2/2] (na); Euxoa messoria Harris [16/27] (na); Euxoa ochrogaster Guenée [10/18] (na; pl); Euxoa scandens Riley [9/14] (na); Euxoa tessellata Harris [15/28] (na); Feltia jaculifera Guenée [16/30] (na); Feltia subgothica Haworth [9/18] (cm; na; nw; pl); Helicoverpa armigera Hübner [40/102] (af; au; cm; ia; na; nt; nz; or; ow; pl); Helicoverpa zea Boddie [38/111] (af; hw; na; nt; nw; or); Lacanobia subjuncta Grote and Robinson [12/14] (na); Lacinipolia renigera Stephens [12/18] (na; pl); Litoprosopus futilis Grote and Robinson [2/3] (na); Lycophotia porphyrea Denis and Schiff. [7/12] (hw; pl); Mamestra brassicae Linnaeus [14/27] (or; pl); Mamestra configurata Walker [16/33] (na; nt); Mamestra curialis Smith [8/8] (na); Megalographa biloba Stephens [15/22] (na; nw; pl); Melanchra picta Harris [26/48] (hl; na); Noctua pronuba Linnaeus [15/22] (hl; na; or; pl); Papaipema nebris Guenée [31/86] (na); Peridroma saucia Hübner [40/86] (cm; na; nt; pl); Pseudaletia unipuncta Haworth [18/53] (au; cm; hw; na; nt; or; pl); Pseudoleucania bilitura Guenée [3/4] (nt); Pseudoplusia includens Walker [22/46] (na; nt); Rachiplusia nu Guenée [9/18] (nt); Spaelotis clandestina Harris [18/25] (na); Spodoptera dolichos Fabricius [14/22] (na; nt); Spodoptera eridania Stoll [31/63] (na; nt; nw); Spodoptera exigua Hübner [35/83] (af; au; cm; hw; na; or; pl); Spodoptera frugiperda Smith [34/91] (af; cm; na; nt; nw); Spodoptera littoralis Boisduval [25/43] (af; na; or; ow; pl); Spodoptera litura Fabricius [69/ 166] (af; au; cm; ia; nt; or; ow); Spodoptera ornithogalli Guenée [25/53] (cm; na; nt); Sunira bicolorago Guenée [8/9] (na); Syngrapha circumflexa Linnaeus [7/8] (af; or; pl); Tiracola plagiata Walker [30/54] (au; ia; or); Trichoplusia ni Hübner [27/65] (af; cm; hw; na; nt; or; pl); Trichoplusia ni brassicae Riley [1/1] (or); Trichoplusia orichalcea Fabricius [24/57] (af; au; or; ow); Trichordestra legitima Grote [11/22] (na); Xestia c-nigrum Linnaeus [31/51] (hl; na; or; pl); Xylena vetusta Hübner [13/21] (na; pl).

Nymphalidae: Amauris tartarea Mabille [1/1] (af).

Pieridae: Appias libythea Fabricius [3/5] (or); Appias libythea peducaea Fruhstorfer [2/2] (or); Artogeia canidia Linnaeus [2/4] (or); Ascia monuste Linnaeus [5/14] (na; nt; nw); Ascia monuste automate Burmeister [1/1] (nt); Ascia monuste eubotea Godart [4/7] (nt); Ascia monuste monuste Linnaeus [4/7] (nt); Hebomoia glaucippe Linnaeus [2/5] (or); Hesperocharis marchalii marchali Guérin-Méneville [3/4] (nt); Phoebis statira Cramer [2/2] (nt); Pieris brassicae Linnaeus [6/24] (cm; or; pl); Pieris canidia Sparrman [4/10] (or); Pieris napi Linnaeus [4/21] (hl; na; or; pl); Pieris pylotis Godart [2/3] (nt); Pieris rapae Linnaeus [6/31] (au; cm; hw; na; nz; or; pl); Pieris rapae crucivora Boisduval [3/6] (or; ow); Pieris rapae rapae Linnaeus [4/14] (au; cm); Pontia protodice Boisduval and LeC. [3/23] (na; nt); Tatochila autodice Hübner [4/9] (nt).

Psychidae: Apterona crenulella helix Siebold [19/ 39] (pl).

Pyralidae: Chilo suppressalis Walker [3/19] (af; au; hw; ia; na; or; ow); Crocidolomia pavonana Fabricius [7/13] (af; au; cm; or; ow); Eustixia pupula Hübner [2/3] (na); Evergestis rimosalis Guenée [1/2] (cm; na; nt); Hellula phidilealis Walker [3/6] (cm; na; nt); Hellula rogatalis Hulst [2/5] (na); Hellula undalis Fabricius [4/11] (af; au; hw; ia; or; ow); Herpetogramma submarginalis Swinhoe [6/9] (au; or); Loxostege sticticalis Linnaeus [17/35] (hl; na; pl); Plodia interpunctella Hübner [25/48] (af; cm; na; nt; or; pl); Udea ferrugalis Hübner [9/16] (af; or; pl); Udea rubigalis Guenée [16/28] (na; nt; nw).

Sphingidae: Hyles lineata Fabricius [36/61] (af; au; na; nt; nw; pl). 
Tineidae: Trachycentra calamias Meyrick [4/4] (au).

Tortricidae: Amorbia emigratella Busck [22/30] (hw; na; nt); Cnephasia asseclana Denis and Schiff. [9/15] (na; pl); Selania leplastriana Curtis [1/5] (pl).

Yponomeutidae: Leuroperna sera Meyrick [1/1] (au; or; ow); Plutella xylostella Linnaeus [11/22] (af; au; cm; hw; ia; na; nt; or; pl).

\section{Brassica oleracea acephala}

Pieridae: Ascia monuste Linnaeus [5/14] (na; nt; nw); Ascia monuste monuste Linnaeus [4/7] (nt); Pieris rapae Linnaeus [6/31] (au; cm; hw; na; nz; or; pl).

Sphingidae: Hyles lineata Fabricius [36/61] (af; au; na; nt; nw; pl).

Yponomeutidae: Plutella xylostella Linnaeus [11/ 22] (af; au; cm; hw; ia; na; nt; or; pl).

\section{Brassica oleracea botrytis}

Geometridae: Xanthorhoe fluctuata Linnaeus [2/ 7] (pl).

Lymantriidae: Euproctis varians Walker [9/17] (or); Sphrageidus virguncula Walker [12/25] (or).

Noctuidae: Aegoceropsis rectilinea Boisduval [7/ 9] (af); Melanchra picta Harris [26/48] (hl; na); Spodoptera litura Fabricius [69/166] (af; au; cm; ia; nt; or; ow); Trichoplusia orichalcea Fabricius [24/57] (af; au; or; ow).

Pieridae: Ascia monuste Linnaeus [5/14] (na; nt; nw); Pieris brassicae Linnaeus [6/24] (cm; or; pl); Pieris rapae Linnaeus [6/31] (au; cm; hw; na; nz; or; pl); Pieris rapae crucivora Boisduval [3/6] (or; ow); Pieris rapae rapae Linnaeus [4/14] (au; cm); Pontia protodice Boisduval and LeC. [3/23] (na; nt).

Pyralidae: Crocidolomia pavonana Fabricius [7/ 13] (af; au; cm; or; ow).

Tortricidae: Clepsis spectrana Treitschke [22/32] (na; pl); Selania leplastriana Curtis [1/5] (pl).

Yponomeutidae: Plutella xylostella Linnaeus [11/ 22] (af; au; cm; hw; ia; na; nt; or; pl).

\section{Brassica oleracea bullata}

Noctuidae: Agrotis segetum Denis and Schiff. [21/ 45] (af; or; ow; pl); Argyrogramma signata Fabricius [7/12] (af; au; or; ow); Spodoptera litura
Fabricius [69/166] (af; au; cm; ia; nt; or; ow); Syngrapha circumflexa Linnaeus [7/8] (af; or; pl).

Pyralidae: Crocidolomia pavonana Fabricius [7/ 13] (af; au; cm; or; ow); Hellula undalis Fabricius [4/11] (af; au; hw; ia; or; ow).

Yponomeutidae: Plutella xylostella Linnaeus [11/ 22] (af; au; cm; hw; ia; na; nt; or; pl).

\section{Brassica oleracea capitata}

Arctiidae: Estigmene acrea Drury [23/46] (na; nt; nw); Spilosoma lubricipeda Linnaeus [15/20] (or; pl); Teracotona submacula Walker [4/5] (af).

Gelechiidae: Dichomeris oceanis Meyrick [3/5] (pl).

Geometridae: Scopula fibulata Guenée [6/7] (or).

Lasiocampidae: Chondrostega tingitana Powell [3/3] (pl).

Lymantriidae: Euproctis varians Walker [9/17] (or); Sphrageidus virguncula Walker [12/25] (or).

Noctuidae: Agrotis clavis Hufnagel [5/6] (or; pl); Agrotis ipsilon Hufnagel [30/74] (af; au; cm; hw; ia; na; nt; nz; or; ow; pl); Agrotis repleta Walker [11/20] (nt); Agrotis subterranea Fabricius [17/39] (na; nt; nw); Argyrogramma verruca Fabricius [13/ 17] (na; nt; nw); Autographa gamma Linnaeus [25/ 75] (cm; na; nt; pl); Autographa nigrisigna Walker [7/13] (or; ow); Chrysodeixis eriosoma Doubleday [18/29] (au; ia; or; pl); Cornutiplusia circumflexa Linnaeus [5/5] (pl); Discestra trifolii Hufnagel [17/ 34] (cm; na; or; pl); Euxoa messoria Harris [16/27] (na); Euxoa nigricans Linnaeus [11/12] (hl; pl); Euxoa ochrogaster Guenée [10/18] (na; pl); Euxoa tritici Linnaeus [8/13] (pl); Helicoverpa armigera Hübner [40/102] (af; au; cm; ia; na; nt; nz; or; ow; pl); Lacanobia nevadae Grote [6/6] (na); Lacanobia oleracea Linnaeus [22/41] (pl); Lacanobia pisi Linnaeus [7/11] (pl); Mamestra brassicae Linnaeus [14/27] (or; pl); Melanchra picta Harris [26/48] (hl; na); Mocis latipes Guenée [10/37] (na; nt; nw); Naenia typica Linnaeus [15/ 24] (or; pl); Nephelodes minians Guenée [7/12] (na); Noctua pronuba Linnaeus [15/22] (hl; na; or; pl); Peridroma saucia Hübner [40/86] (cm; na; nt; pl); Phlogophora meticulosa Linnaeus [12/23] (pl); Pseudoplusia includens Walker [22/46] (na; nt); Spodoptera eridania Stoll [31/63] (na; nt; nw); Spodoptera litura Fabricius [69/166] (af; au; cm; 
ia; nt; or; ow); Trichoplusia ni Hübner [27/65] (af; cm; hw; na; nt; or; pl); Trichoplusia orichalcea Fabricius [24/57] (af; au; or; ow); Xestia c-nigrum Linnaeus [31/51] (hl; na; or; pl).

Papilionidae: Papilio polyxenes Fabricius [5/29] (na; nt; nw).

Pieridae: Appias drusilla Cramer [3/4] (na; nt); Ascia monuste Linnaeus [5/14] (na; nt; nw); Ascia monuste monuste Linnaeus [4/7] (nt); Leptophobia aripa Boisduval [2/2] (nt); Pieris brassicae Linnaeus [6/24] (cm; or; pl); Pieris canidia canidia Sparrman [3/6] (or); Pieris daplidice Linnaeus [2/ 9] (af; or; ow; pl); Pieris daplidice albidice Oberthür [1/1] (pl); Pieris napi Linnaeus [4/21] (hl; na; or; pl); Pieris rapae Linnaeus [6/31] (au; cm; hw; na; nz; or; pl); Pieris rapae crucivora Boisduval [3/6] (or; ow); Pieris rapae rapae Linnaeus [4/14] (au; cm); Pontia protodice Boisduval and LeC. [3/23] (na; nt); Tatochila autodice Hübner [4/9] (nt).

Pyralidae: Crocidolomia pavonana Fabricius [7/ 13] (af; au; cm; or; ow); Hellula hydralis Guenée [1/1] (au); Hellula phidilealis Walker [3/6] (cm; na; nt); Hellula undalis Fabricius [4/11] (af; au; hw; ia; or; ow); Herpetogramma submarginalis Swinhoe [6/9] (au; or).

Tortricidae: Selania leplastriana Curtis [1/5] (pl).

Yponomeutidae: Plutella xylostella Linnaeus [11/ 22] (af; au; cm; hw; ia; na; nt; or; pl).

\section{Brassica oleracea gemmifera}

Noctuidae: Mamestra brassicae Linnaeus [14/27] (or; pl).

Pieridae: Pieris brassicae Linnaeus [6/24] (cm; or; pl); Pieris napi Linnaeus [4/21] (hl; na; or; pl); Pieris rapae Linnaeus [6/31] (au; cm; hw; na; nz; or; pl); Pieris rapae rapae Linnaeus [4/14] (au; $\mathrm{cm})$.

Pyralidae: Evergestis forficalis Linnaeus [2/4] (ow; pl).

Tortricidae: Clepsis spectrana Treitschke [22/32] (na; pl).

Yponomeutidae: Plutella xylostella Linnaeus [11/ 22] (af; au; cm; hw; ia; na; nt; or; pl).

\section{Brassica oleracea gongylodes}

Noctuidae: Spodoptera litura Fabricius [69/166] (af; au; cm; ia; nt; or; ow).
Pieridae: Pieris brassicae Linnaeus [6/24] (cm; or; pl).

\section{Brassica oleracea italica}

Gelechiidae: Phthorimaea operculella Zeller [6/ 14] (af; au; cm; hw; na; nt; nw; or; ow; pl).

Noctuidae: Agrotis ipsilon Hufnagel [30/74] (af; au; cm; hw; ia; na; nt; nz; or; ow; pl).

Pieridae: Pieris rapae rapae Linnaeus [4/14] (au; $\mathrm{cm})$.

Yponomeutidae: Plutella xylostella Linnaeus [11/ 22] (af; au; cm; hw; ia; na; nt; or; pl).

\section{Brassica rapa}

Arctiidae: Spilosoma obliqua Walker [27/54] (or); Spilosoma virginica Fabricius [44/86] (cm; na).

Geometridae: Anacamptodes fragilaria Grossbeck [15/24] (na).

Noctuidae: Achaea janata Linnaeus [33/74] (af; au; hw; ia; or); Agrotis ipsilon Hufnagel [30/74] (af; au; cm; hw; ia; na; nt; nz; or; ow; pl); Agrotis segetum Denis and Schiff. [21/45] (af; or; ow; pl); Agrotis subterranea Fabricius [17/39] (na; nt; nw); Agrotis vetusta Walker [13/20] (na); Autographa californica Speyer [26/44] (na); Autographa gamma Linnaeus [25/75] (cm; na; nt; pl); Discestra trifolii Hufnagel [17/34] (cm; na; or; pl); Euxoa auxiliaris Grote [16/42] (na); Euxoa messoria Harris [16/27] (na); Feltia jaculifera Guenée [16/ 30] (na); Lacanobia oleracea Linnaeus [22/41] (pl); Lacanobia suasa Denis and Schiff. [15/25] (pl); Lacinipolia renigera Stephens [12/18] (na; pl); Mamestra brassicae Linnaeus [14/27] (or; pl); Mamestra configurata Walker [16/33] (na; nt); Melanchra picta Harris [26/48] (hl; na); Mocis latipes Guenée [10/37] (na; nt; nw); Noctua pronuba Linnaeus [15/22] (hl; na; or; pl); Peridroma saucia Hübner [40/86] (cm; na; nt; pl); Spodoptera dolichos Fabricius [14/22] (na; nt); Spodoptera frugiperda Smith [34/91] (af; cm; na; nt; nw); Spodoptera litura Fabricius [69/166] (af; au; cm; ia; nt; or; ow); Spodoptera ornithogalli Guenée [25/53] (cm; na; nt); Trichoplusia ni Hübner [27/65] (af; cm; hw; na; nt; or; pl); Trichordestra legitima Grote [11/22] (na); Tripseuxoa strigata Hampson [4/7] (nt); Xestia cnigrum Linnaeus [31/51] (hl; na; or; pl).

Pieridae: Anthocharis sara Lucas [1/16] (na); Ascia monuste Linnaeus [5/14] (na; nt; nw); Ascia 
monuste monuste Linnaeus [4/7] (nt); Belenois zochalia Boisduval [3/8] (af); Euchloe ausonides Lucas [1/12] (na); Hesperocharis marchalii marchali Guérin-Méneville [3/4] (nt); Pieris brassicae Linnaeus [6/24] (cm; or; pl); Pieris napi Linnaeus [4/21] (hl; na; or; pl); Pieris rapae Linnaeus [6/31] (au; cm; hw; na; nz; or; pl); Pieris rapae rapae Linnaeus [4/14] (au; cm); Pontia protodice Boisduval and LeC. [3/23] (na; nt); Tatochila autodice Hübner [4/9] (nt).

Psychidae: Apterona crenulella helix Siebold [19/ 39] (pl).

Pyralidae: Corcyra cephalonica Stainton [19/39] (af; cm; hw; na; nt; or); Crocidolomia pavonana Fabricius [7/13] (af; au; cm; or; ow); Elasmopalpus lignosellus Zeller [23/38] (cm; na; nt; nw); Evergestis pallidata Hufnagel [1/5] (hl; na; pl); Hellula phidilealis Walker [3/6] (cm; na; nt); Hellula undalis Fabricius [4/11] (af; au; hw; ia; or; ow); Ostrinia nubilalis Hübner [16/39] (au; cm; hl; na; or; pl).

Sphingidae: Hyles lineata Fabricius [36/61] (af; au; na; nt; nw; pl).

Yponomeutidae: Leuroperna sera Meyrick [1/1] (au; or; ow); Plutella xylostella Linnaeus [11/22] (af; au; cm; hw; ia; na; nt; or; pl).

\section{Cakile edentula}

Noctuidae: Euxoa detersa Walker [8/14] (na).

Pieridae: Ascia monuste Linnaeus [5/14] (na; nt; nw); Pieris rapae Linnaeus [6/31] (au; cm; hw; na; nz; or; pl); Pontia protodice Boisduval and LeC. [3/ 23] (na; nt).

\section{Cakile maritima}

Arctiidae: Platyprepia virginalis Boisduval [5/6] (na).

Noctuidae: Agrotis ripae Hübner [2/3] (pl); Euxoa cursoria Hufnagel [8/9] (na; pl); Trichoplusia ni Hübner [27/65] (af; cm; hw; na; nt; or; pl).

Pieridae: Ascia monuste Linnaeus [5/14] (na; nt; nw); Pieris brassicae Linnaeus [6/24] (cm; or; pl); Pieris daplidice Linnaeus [2/9] (af; or; ow; pl).

\section{Cardamine californica}

Pieridae: Anthocharis sara Lucas [1/16] (na); Pieris napi Linnaeus [4/21] (hl; na; or; pl).

\section{Hirschfeldia incana}

Arctiidae: Arachnis picta Packard [8/13] (na); Arachnis picta picta Packard [3/3] (na); Notarctia proxima Guérin-Méneville [8/9] (na); Spilosoma vestalis Packard [8/10] (na).

Pieridae: Anthocharis sara Lucas [1/16] (na); Euchloe ausonides Lucas [1/12] (na); Pieris protodice Boisduval and Le Co [1/2] (na); Pieris rapae Linnaeus [6/31] (au; cm; hw; na; nz; or; pl); Pieris rapae rapae Linnaeus [4/14] (au; cm); Pontia protodice Boisduval and LeC. [3/23] (na; $\mathrm{nt})$; Zegris eupheme Esper [1/1] (pl).

\section{Raphanus raphanistrum}

Geometridae: Xanthorhoe fluctuata Linnaeus [2/ 7] (pl).

Noctuidae: Autographa gamma Linnaeus [25/75] (cm; na; nt; pl).

Pieridae: Ascia monuste monuste Linnaeus [4/7] (nt); Pieris napi Linnaeus [4/21] (hl; na; or; pl); Pieris rapae Linnaeus [6/31] (au; cm; hw; na; nz; or; pl); Pieris rapae rapae Linnaeus [4/14] (au; $\mathrm{cm})$; Tatochila autodice Hübner [4/9] (nt).

Psychidae: Apterona crenulella helix Siebold [19/ 39] (pl).

Tortricidae: Tortrix capensana Walker [8/10] (af).

\section{Raphanus sativus}

Arctiidae: Ocnogyna loewii Zeller [4/4] (pl); Spilosoma virginica Fabricius [44/86] (cm; na).

Geometridae: Xanthorhoe designata Hufnagel [2/ 6] (na; pl).

Hepialidae: Endoclita excrescens Butler [3/4] (ow; pl).

Noctuidae: Achaea janata Linnaeus [33/74] (af; au; hw; ia; or); Agrotis ipsilon Hufnagel [30/74] (af; au; cm; hw; ia; na; nt; nz; or; ow; pl); Agrotis longidentifera Hampson [7/9] (af); Apamea devastator Brace [9/19] (na); Brithysana speyeri Felder and Rogenh. [9/12] (af); Chrysodeixis eriosoma Doubleday [18/29] (au; ia; or; pl); Crassivesica bochus Morrison [2/2] (na); Discestra trifolii Hufnagel [17/34] (cm; na; or; pl); Euxoa auxiliaris Grote [16/42] (na); Euxoa messoria Harris [16/27] (na); Euxoa ochrogaster Guenée [10/18] (na; pl); Euxoa scandens Riley [9/14] (na); Euxoa tessellata Harris [15/28] (na); Hydraecia 
micacea Esper [15/27] (hl; na; pl); Mamestra brassicae Linnaeus [14/27] (or; pl); Melanchra picta Harris [26/48] (hl; na); Peridroma saucia Hübner [40/86] (cm; na; nt; pl); Pseudaletia unipuncta Haworth [18/53] (au; cm; hw; na; nt; or; pl); Rachiplusia nu Guenée [9/18] (nt); Spodoptera exigua Hübner [35/83] (af; au; cm; hw; na; or; pl); Spodoptera litura Fabricius [69/166] (af; au; cm; ia; nt; or; ow); Spodoptera pecten Guenée [7/15] (ia; or); Trichoplusia ni Hübner [27/65] (af; cm; hw; na; nt; or; pl); Trichoplusia orichalcea Fabricius [24/57] (af; au; or; ow).

Nymphalidae: Vanessa cardui Linnaeus [25/104] (af; au; cm; hw; na; or; pl).

Pieridae: Anthocharis sara Lucas [1/16] (na); Artogeia canidia Linnaeus [2/4] (or); Ascia monuste Linnaeus [5/14] (na; nt; nw); Euchloe ausonides Lucas [1/12] (na); Pieris brassicae Linnaeus [6/24] (cm; or; pl); Pieris daplidice Linnaeus [2/9] (af; or; ow; pl); Pieris napi Linnaeus [4/21] (hl; na; or; pl); Pieris rapae Linnaeus [6/31] (au; cm; hw; na; nz; or; pl); Pieris rapae crucivora Boisduval [3/6] (or; ow); Pieris rapae rapae Linnaeus [4/14] (au; cm); Pontia protodice Boisduval and LeC. [3/23] (na; nt); Tatochila autodice Hübner [4/9] (nt).

Pyralidae: Achyra rantalis Guenée [8/14] (na; nt; nw); Crocidolomia pavonana Fabricius [7/13] (af; au; cm; or; ow); Evergestis forficalis Linnaeus [2/4] (ow; pl); Evergestis pallidata Hufnagel [1/5] (hl; na; pl); Hellula phidilealis Walker [3/6] (cm; na; nt); Hellula rogatalis Hulst [2/5] (na); Hellula undalis Fabricius [4/11] (af; au; hw; ia; or; ow); Udea rubigalis Guenée [16/28] (na; nt; nw).

Sphingidae: Manduca sexta Linnaeus [7/16] (na; nt; nw).

Yponomeutidae: Plutella xylostella Linnaeus [11/ 22] (af; au; cm; hw; ia; na; nt; or; pl).

\section{Sinapis arvensis}

Noctuidae: Spodoptera praefica Grote [16/35] (na).

Pieridae: Anthocharis sara Lucas [1/16] (na); Anthocharis sara sara Lucas [1/7] (na); Euchloe ausonides Lucas [1/12] (na); Pieris rapae Linnaeus [6/31] (au; cm; hw; na; nz; or; pl); Pontia protodice Boisduval and LeC. [3/23] (na; nt).

Pyralidae: Nomophila nearctica Munroe [7/12] (na).

\section{GRAMINEAE}

\section{Oryza glaberrima}

Pyralidae: Maliarpha separatella Ragonot [1/2] (af; ow).

Tortricidae: Dudua aprobola Meyrick [20/37] (af; au; ia; or).

\section{Oryza sativa}

Arctiidae: Alpenus maculosa Stoll [14/24] (af); Amata fortunei de l'Orza [2/2] (or); Amata huebneri Boisduval [1/1] (or); Amsacta lactinea Cramer [26/45] (or); Amsacta lineola Fabricius [8/ 15] (or); Asura calamaria Moore [3/3] (or); Creatonotos gangis Linnaeus [8/19] (au; or); Creatonotos leucanioides Holland [4/4] (af; nt); Creatonotos punctivitta Walker [1/1] (af); Estigmene senegalensis Rothschild [1/1] (af); Micralarctia punctulata Wallengren [3/3] (af); Paracles laboulbeni Bar [1/1] (nt); Schistophleps bipuncta Hampson [1/1] (or); Spilosoma nigricosta Holland [1/2] (af); Spilosoma scortilla Wallengren [1/1] (af); Thumatha fuscescens Walker [1/1] (or).

Cossidae: Phragmataecia purpureus Fletcher [1/4] (or).

Eupterotidae: Eupterote minor Moore [2/2] (or); Nisaga simplex Walker [1/2] (or).

Gelechiidae: Athrips studiosa Meyrick [1/1] (or); Helcystogramma arotraea Meyrick [1/4] (or); Helcystogramma nr. malacogramma Meyrick [1/1] (af); Pityocona xeropis Meyrick [1/1] (or); Sitotroga cerealella Olivier [2/8] (af; cm; hw; na; $\mathrm{nt}$; or).

Geometridae: Pamphlebia rubrolimbraria Guenée [1/1] (or); Scopula emissaria Walker [6/9] (or).

Hesperiidae: Ampittia dioscorides Fabricius [1/1] (or); Ampittia dioscorides camertes Hewitson [1/1] (or); Ampittia dioscorides etura Mabille [1/1] (or); Ancyloxypha numitor Fabricius [1/8] (na); Apaustus menes Stoll [1/1] (nt); Baoris pagana de Nicéville [1/1] (or); Borbo borbonica Boisduval [1/ 5] (af); Borbo cinnara Wallace [1/15] (au; ia; or); Borbo fanta Evans [1/2] (af); Borbo fatuellus Hopffer [1/5] (af); Borbo impar Mabille [1/1] (au); Gegenes hottentota Latreille [1/4] (af); Gegenes niso Linnaeus [1/4] (af); Lerodea eufala Edwards [1/9] (na; nt; nw); Nyctelius nyctelius Latreille [1/6] (nt); Oriens gola Moore [1/3] (or); Panoquina ocola Edwards [1/3] (na; nt); Panoquina sylvicola 
Herrich-Schäffer [1/8] (nt); Parnara amalia Semper [1/2] (au); Parnara bada sida Waterhouse [1/2] (au); Parnara ganga Evans [1/2] (or); Parnara guttatus Bremer and Grey [2/9] (or; ow; pl); Parnara guttatus apostata Snellen [2/5] (or); Parnara guttatus guttatus Bremer and Grey [1/4] (or); Parnara naso Fabricius [2/3] (af; or); Parnara naso bada Moore [2/6] (au; or); Parnara naso monasi Trimen [1/1] (af); Parnara poutieri Boisduval [1/1] (af); Pelopidas agna Moore [1/3] (or); Pelopidas agna agna Moore [1/4] (or); Pelopidas conjuncta Herrich-Schäffer [1/7] (or; ow); Pelopidas conjuncta conjuncta HerrichSchäffer [1/6] (or); Pelopidas lyelli lyelli Rothschild [1/3] (au); Pelopidas mathias Fabricius [3/11] (af; ia; or; ow); Pelopidas mathias mathias Fabricius [2/5] (or); Perichares philetes Gmelin [2/ 12] (nt); Polytremis pellucida Murray [1/1] (ow); Potanthus dara Kollar [1/3] (or); Potanthus omaha Edwards [2/8] (or); Potanthus tropica Plötz [1/1] (or); Prosopalpus styla Evans [1/1] (af); Pseudoborbo bevani Moore [3/6] (or); Taractrocera ceramas Hewitson [1/1] (or); Taractrocera ina ina Waterhouse [1/4] (au); Taractrocera papyria papyria Boisduval [2/11] (au); Telicota augias Linnaeus [1/5] (ia; or); Telicota augias argilus Waterhouse [1/1] (au); Telicota bambusae Moore [2/6] (au; or); Telicota ohara Plötz [1/2] (or); Wallengrenia drury Latreille [1/2] (nt); Wallengrenia otho Smith [1/4] (nt; nw); Wallengrenia premnas Wallengren [1/4] (nt).

Lasiocampidae: Lenodora vittata Walker [2/3] (or).

Limacodidae: Parasa bicolor Walker [1/3] (or); Parasa lepida Cramer [35/77] (ia; or; ow); Thosea sinensis Walker [15/18] (au; ia; or; ow).

Lymantriidae: Cifuna locuples Walker [6/12] (or; pl); Euproctis varians Walker [9/17] (or); Euproctis virgo Swinhoe [2/2] (or); Laelia coenosa Hübner [3/2] (or; pl); Laelia fasciata Moore [1/1] (or); Laelia fracta Schaus and Clement [3/4] (af); Laelia rosea Schaus and Clement [1/1] (af); Laelia suffusa Walker [2/6] (or); Leucoma salicis Linnaeus [4/5] (hl; na; pl); Psalis pennatula Fabricius [11/18] (af; or; ow); Sphrageidus virguncula Walker [12/25] (or); Sphrageidus xanthorrhoea Kollar [10/18] (or).

Noctuidae: Achaea catocaloides Guenée [12/14] (af); Acontia crocata Guenée [2/3] (or); Actebia fennica Tauscher [25/47] (hl; na; pl); Agrotis ipsilon Hufnagel [30/74] (af; au; cm; hw; ia; na; nt; nz; or; ow; pl); Agrotis longidentifera Hampson [7/ 9] (af); Agrotis repleta Walker [11/20] (nt); Agrotis subterranea Fabricius [17/39] (na; nt; nw); Aletia exsanguis Guenée [1/2] (or); Aletia panarista Fletcher [1/1] (af); Aletia umbrigera Saalmüller [1/ 1] (af); Anicla ignicans Guenée [4/10] (nt; pl); Anticarsia gemmatalis Hübner [4/21] (na; nt); Anticarsia irrorata Fabricius [4/16] (af; au; or; ow); Ariathisa abyssinia Guenée [4/5] (af; or); Bathytricha truncata Walker [4/7] (au); Busseola fusca Fuller [3/8] (af); Chalciope alcyona Druce [1/ 1] (au); Cretonia vegetus Swinhoe [2/2] (or); Eublemma anachoresis Wallengren [3/2] (af; au; or); Faronta albilinea Hübner [5/23] (na; nt; nw); Faronta quadrannulata Morrison [1/4] (nt); Gnamptonyx innexa Walker [1/1] (af); Grammodes bifasciata Petagna [4/4] (af; pl); Grammodes geometrica Fabricius [7/9] (af; or; ow); Grammodes stolida Fabricius [8/9] (af; or; ow); Helicoverpa armigera Hübner [40/102] (af; au; cm; ia; na; nt; nz; or; ow; pl); Helicoverpa zea Boddie [38/111] (af; hw; na; nt; nw; or); Hiccoda nigripalpis Walker [1/1] (or); Leucania albistigma Moore [1/1] (or); Leucania compta Moore [1/1] (or); Leucania humidicola Guenée [1/6] (nt); Leucania insularis Butler [1/2] (or); Leucania irregularis Walker [1/3] (au; or); Leucania jaliscana Schaus [1/4] (nt); Leucania latiuscula Herrich-Schäffer [1/12] (na; nt); Leucania loreyi Duponchel [5/17] (af; au; or; ow; pl); Leucania microsticha Hampson [1/5] (nt); Leucania phaea Hampson [1/4] (af; pl); Leucania polystrota Hampson [1/4] (nt); Leucania roseilinea Walker [1/ 1] (or); Leucania venalba Moore [1/2] (au; or); Maliattha signifera Walker [1/1] (or); Mocis frugalis Fabricius [5/15] (af; au; ia; or); Mocis latipes Guenée [10/37] (na; nt; nw); Mocis punctularis Hübner [2/3] (af; nt); Mocis repanda Fabricius [6/5] (af; nt); Mocis trifasciata Stephens [2/6] (au); Mythimna l-album Linnaeus [1/2] (pl); Mythimna vitellina Hübner [2/2] (pl); Mythimna zeae Duponchel [1/3] (ow); Naranga aenescens Moore [2/5] (or; ow); Naranga diffusa Walker [1/2] (or; ow); Nodaria externalis Guenée [2/2] (or); Pandesma robusta Walker [2/2] (af; or); Plusia festucae Linnaeus [2/4] (na; ow; pl); Plusia putnami Grote [4/6] (na; ow; pl); Protodeltote distinguenda Staudinger [1/1] (pl); Pseudaletia 
adultera Schaus [4/14] (nt); Pseudaletia separata Walker [12/32] (au; ia; nz; or); Pseudaletia unipuncta Haworth [18/53] (au; cm; hw; na; nt; or; pl); Rhododactyla elicrina Felder [1/1] (af); Rivula atimeta Swinhoe [1/1] (or); Rivula bioculalis Moore [1/2] (or); Rivula continentalis Gaede [1/1] (af); Rivula innotabilis Swinhoe [1/1] (or); Sciomesa biluma Nye [1/3] (af); Sesamia botanephaga Tams and Bowden [3/10] (af); Sesamia calamistis Hampson [3/13] (af); Sesamia cretica Lederer [2/7] (af; or; ow; pl); Sesamia inferens Walker [3/24] (or; ow); Sesamia nonagrioides Lefèbvre [4/6] (af; ow; pl); Sesamia penniseti Tams and Bowden [1/8] (af); Sesamia uniformis Dudgeon [1/8] (ia; or); Sesamia venosata Moore [1/1] (or); Simplicia robustalis Guenée [5/9] (au; ia; or); Simyra albovenosa Goeze [10/21] (hl; or; ow; pl); Speia vuteria Stoll [3/8] (nt; ow); Spodoptera cilium Guenée [4/8] (af; or; ow; pl); Spodoptera compta Walker [1/5] (or); Spodoptera exempta Walker [7/29] (af; au; hw; or; ow); Spodoptera exigua Hübner [35/83] (af; au; cm; hw; na; or; pl); Spodoptera frugiperda Smith [34/91] (af; cm; na; nt; nw); Spodoptera littoralis Boisduval [25/43] (af; na; or; ow; pl); Spodoptera litura Fabricius [69/166] (af; au; cm; ia; nt; or; ow); Spodoptera mauritia Boisduval [7/20] (af; au; cm; hw; ia; or; ow); Spodoptera pecten Guenée [7/15] (ia; or); Spodoptera praefica Grote [16/35] (na); Spodoptera triturata Walker [1/3] (af); Trichoplusia indicator Walker [1/1] (af); Xanthodes graellsii Feisthamel [3/10] (af; or; ow).

Nolidae: Earias cupreoviridis Walker [4/10] (af; au; or; ow); Nola squalida Staudinger [4/4] (ia; or).

Notodontidae: Antheua woerdeni Snellen [2/2] (af); Phalera combusta Walker [1/4] (or).

Nymphalidae: Acraea terpsichore Linnaeus [6/11] (af); Bicyclus dorothea Cramer [1/1] (af); Bicyclus vulgaris Butler [1/1] (af); Junonia almana Linnaeus [11/22] (ia; or; pl); Junonia atlites Linnaeus [6/14] (ia; or); Junonia sophia Fabricius [2/8] (af); Melanitis leda Linnaeus [2/33] (af; au; or; ow; pl); Melanitis leda ismene Cramer [1/4] (or); Melanitis leda leda Linnaeus [1/4] (or); Melanitis phedima Cramer [2/18] (or; pl); Minois dryas Scopoli [1/10] (or; pl); Mycalesis gotama Moore [1/9] (or; ow; pl); Mycalesis gotama nanda Fruhstorfer [1/9] (or); Mycalesis horsfieldi Moore [1/3] (or); Mycalesis mamerta Stoll [1/1] (or); Mycalesis mineus Linnaeus [1/8] (or); Mycalesis nr. lorna Grose-Smith [1/1] (au); Mycalesis perseus Fabricius [1/13] (au; or; pl); Mycalesis terminus Fabricius [2/8] (au); Mycalesis visala andamana Moore [1/1] (or); Orsotriaena medus Fabricius [1/4] (au; or); Orsotriaena medus cinerea Butler [1/1] (or); Orsotriaena medus mandata Moore [1/1] (or); Orsotriaena medus medus Fabricius [1/1] (or); Vanessa cardui Linnaeus [25/ 104] (af; au; cm; hw; na; or; pl).

Psychidae: Brachycyttarus griseus Joannis [5/6] (or); Mahasena graminivora Hampson [2/3] (or).

Pterophoridae: Exelastis atomosa Walsingham [2/ 6] (af; or; ow).

Pyralidae: Achyra coelatalis Walker [1/3] (af; or); Adelpherupa flavescens Hampson [1/1] (af); Aglossa dimidiatus Haworth [2/2] (pl); Ancylolomia chrysographellus Kollar [1/3] (or); Ancylolomia indica Felder and Rogenh. [1/2] (or); Ancylolomia inornata Staudinger [1/3] (af); Ancylolomia japonica Zeller [1/1] (ow); Ancylosis convexella Lederer [1/1] (af); Antigastra catalaunalis Duponchel [5/7] (af; au; cm; or); Bleszynskia malacelloides Bleszynski [1/1] (or); Bleszynskia malacellus Duponchel [2/5] (af; au; ow); Bradina admixtalis Walker [2/2] (af; ow); Cadra calidella Guenée [8/10] (af; na; or; pl); Cadra cautella Walker [35/61] (af; au; cm; na; nt; or); Carectocultus bivitta Möschler [1/1] (nt); Catagela adjurella Walker [1/1] (or); Chilo agamemnon Bleszynski [1/5] (af; ow); Chilo aleniella Strand [1/1] (af); Chilo auricilia Dudgeon [1/9] (au; or); Chilo christophi Bleszynski [1/2] (pl); Chilo diffusilinea Joannis [1/4] (af); Chilo infuscatellus Snellen [1/3] (au; ia; or; ow); Chilo nr. partellus Swinhoe [1/1] (or); Chilo partellus Swinhoe [1/7] (af; or; ow); Chilo phragmitellus Hübner [1/2] (pl); Chilo plejadellus Zincken [1/1] (na; or); Chilo polychrysa Meyrick [2/11] (au; or; pl); Chilo sacchariphagus Bojer [1/7] (af; or; ow); Chilo suppressalis Walker [3/19] (af; au; hw; ia; na; or; ow); Chilo zacconius Bleszynski [1/5] (af); Cnaphalocrocis bilinealis Hampson [1/1] (or); Cnaphalocrocis exigua Butler [1/4] (au; ia; or); Cnaphalocrocis medinalis Guenée [4/14] (au; or; ow); Cnaphalocrocis patnalis Bradley [2/7] (or); Cnaphalocrocis poeyalis Boisduval [1/1] (au; ia); Cnaphalocrocis trapezalis Guenée [1/14] (af; au; cm; na; nt; or); Coniesta ignefusalis Hampson [1/4] (af); Corcyra cephalonica Stainton [19/39] (af; cm; hw; na; nt; or); Crypsiptya coclesalis Walker [4/12] 
(or; ow); Cryptoblabes gnidiella Millière [30/49] (af; cm; hw; na; nt; or; pl); Diatraea lineolata Walker [1/5] (nt; nw); Diatraea saccharalis Fabricius [2/19] (na; nt; nw; or); Doloessa viridis Zeller [10/12] (or); Donacaula dodatellus Walker [2/2] (or); Donacaula forficella Thunberg [2/4] (or; pl); Elasmopalpus lignosellus Zeller [23/38] (cm; na; nt; nw); Eldana saccharina Walker [3/8] (af); Elophila difflualis Snellen [5/5] (or; ow; pl); Elophila nymphaeata Linnaeus [6/7] (pl); Endotricha melanobasis Hampson [1/1] (or); Endotricha puncticostalis Walker [2/2] (au; or); Eoreuma loftini Dyar [1/6] (na); Ephestia elutella Hübner [15/17] (cm; na; nt; or; pl); Ephestia kuehniella Zeller [12/21] (hl; na; nt; pl); Epina dichromella Walker [1/1] (or); Eurrhyparodes bracteolalis Zeller [2/2] (or); Herpetogramma licarsisalis Walker [6/15] (af; au; or; ow); Mabra eryxalis Walker [1/1] (or); Maliarpha separatella Ragonot [1/2] (af; ow); Marasmia ruralis Walker [1/1] (or); Marasmia venilialis Walker [1/8] (af; au; ia; or); Maruca vitrata Fabricius [6/16] (cm; na; or); Metoeca foedalis Guenée [1/1] (or); Monoctenocera brachiella Hampson [2/6] (or); Niphadoses palleucus Common [1/1] (au); Nymphula ussuriensis Rebel [1/1] (pl); Panalipa immeritalis Walsingham [1/1] (or); Paralipsa gularis Zeller [22/28] (hl; hw; na); Parapoynx diminutalis Snellen [5/6] (hl; na; nt; or; pl); Parapoynx fluctuosalis Zeller [3/3] (au; cm; hw; nt; or; ow); Parapoynx indomitalis Berg [1/1] (nt); Parapoynx stagnalis Zeller [3/3] (af; or; ow); Parapoynx vittalis Bremer [2/2] (pl); Parerupa africana Aurivillius [1/1] (af); Plodia interpunctella Hübner [25/48] (af; cm; na; nt; or; pl); Psara basalis Walker [7/11] (af; or; ow); Rupela albina Becker and Solis [1/1] (nt); Saluria inficita Walker [1/3] (or); Sameodes cancellalis Zeller [3/3] (af; or); Scirpophaga excerptalis Walker [1/3] (ia; or); Scirpophaga gilviberbis Zeller [1/1] (af; or); Scirpophaga incertulas Walker [2/10] (or; ow); Scirpophaga innotata Walker [2/2] (au; ia; or); Scirpophaga melanoclista Meyrick [1/ 1] (af); Scirpophaga nivella Fabricius [2/6] (or; ow); Scirpophaga subumbrosa Meyrick [1/1] (af); Tatobotys biannulalis Walker [2/2] (au); Zovax vangoghi Bleszynski [1/1] (af).

Sphingidae: Macroglossum trochilus trochiloides Butler [1/1] (af).

Thyrididae: Opula spilotata Warren [1/1] (af).
Tineidae: Haplotinea ditella Pierce and Diak. [2/3] (pl); Setomorpha rutella Zeller [19/23] (af; au; cm; ia; na; nt; or; ow).

Zygaenidae: Balataea zebraica Butler [1/2] (or).

\section{MALVACEAE}

\section{Gossypium barbadense}

Cosmopterigidae: Pyroderces falcatella Stainton [8/10] (au; or); Pyroderces ptilodelta Meyrick [5/7] (or); Pyroderces rileyi Walsingham [13/18] (au; hl; hw; na; nt; or); Pyroderces simplex Walsingham [11/17] (af; cm; or; ow; pl).

Cossidae: Zeuzera coffeae Nietner [33/79] (au; ia; or).

Gelechiidae: Pectinophora gossypiella Saunders [6/14] (af; au; cm; hw; ia; na; nt; or; ow; pl).

Gracillariidae: Phyllonorycter triarcha Meyrick [1/1] (af; or).

Nepticulidae: Stigmella gossypii Forbes [1/2] (nt; nw).

Noctuidae: Agrotis subterranea Fabricius [17/39] (na; nt; nw); Alabama argillacea Hübner [3/5] (na; nt; nw); Anomis erosa Hübner [9/21] (af; au; cm; ia; na; nt; or); Anomis flava Fabricius [9/22] (af; au; cm; na; nt; or; ow); Anomis impasta Guenée [1/4] (na; nt; nw); Anomis luridula Guenée [1/1] (nt); Anomis vulpina Butler [1/3] (au); Condica concisa Walker [3/2] (na; nt; or); Elaphria agrotina Guenée [3/3] (nt); Helicoverpa armigera Hübner [40/102] (af; au; cm; ia; na; nt; nz; or; ow; pl); Heliothis virescens Fabricius [19/50] (na; nt; nw); Neogalea sunia Guenée [8/11] (au; cm; hw; na; nt); Spodoptera dolichos Fabricius [14/22] (na; nt); Spodoptera frugiperda Smith [34/91] (af; cm; na; nt; nw); Spodoptera latifascia Walker [16/24] (na; nt; nw); Spodoptera pulchella Herrich-Schäffer [1/ 1] (nt); Trichoplusia ni Hübner [27/65] (af; cm; hw; na; nt; or; pl).

Nolidae: Earias huegeli Rogenhofer [2/3] (au; ia); Earias insulana Boisduval [9/22] (af; au; or; ow; pl); Earias vitella Fabricius [1/10] (au; ia; or).

Pyralidae: Haritalodes derogata Fabricius [10/24] (af; au; cm; or; ow).

Saturniidae: Citheronia regalis Fabricius [18/23] (na).

Tortricidae: Adoxophyes fasciculana Walker [26/ 43] (au; or). 


\section{Gossypium hirsutum}

Cosmopterigidae: Pyroderces rileyi Walsingham [13/18] (au; hl; hw; na; nt; or).

Gelechiidae: Pectinophora gossypiella Saunders [6/14] (af; au; cm; hw; ia; na; nt; or; ow; pl).

Nepticulidae: Stigmella gossypii Forbes [1/2] (nt; nw).

Noctuidae: Agrotis ipsilon Hufnagel [30/74] (af; au; cm; hw; ia; na; nt; nz; or; ow; pl); Alabama argillacea Hübner [3/5] (na; nt; nw); Anomis erosa Hübner [9/21] (af; au; cm; ia; na; nt; or); Anomis illita Guenée [2/11] (nt; ow); Anomis impasta Guenée [1/4] (na; nt; nw); Helicoverpa armigera Hübner [40/102] (af; au; cm; ia; na; nt; nz; or; ow; pl); Helicoverpa zea Boddie [38/111] (af; hw; na; nt; nw; or); Heliothis virescens Fabricius [19/50] (na; nt; nw); Neogalea sunia Guenée [8/11] (au; cm; hw; na; nt); Spodoptera eridania Stoll [31/63] (na; nt; nw); Spodoptera latifascia Walker [16/24] (na; nt; nw); Spodoptera ornithogalli Guenée [25/ 53] (cm; na; nt).

Pyralidae: Achyra rantalis Guenée [8/14] (na; nt; $\mathrm{nw})$; Ephestiodes gilvescentella Ragonot [4/7] (na; nw); Euzophera semifuneralis Walker [13/18] (na; nw); Moodna ostrinella Clemens [9/13] (na; nw); Paralipsa gularis Zeller [22/28] (hl; hw; na).

Tortricidae: Amorbia phaseolana Busck [4/6] (nt); Platynota rostrana Walker [25/42] (na; nt; nw).

\section{Gossypium tomentosum}

Bucculatricidae: Bucculatrix thurberiella Busck [1/2] (hw; na; nt; nw).

Gelechiidae: Pectinophora gossypiella Saunders [6/14] (af; au; cm; hw; ia; na; nt; or; ow; pl).

\section{REFERENCES}

Acciarri N, Vitelli G, Arpaia S, Mennella G, Sunseri F, Rotino GL (2000) Transgenic resistance to the Colorado potato beetle in Bt expressing eggplant fields. Hortscience $\mathbf{3 5}$ : 722

Agrawal AA (1999) Induced responses to herbivory in wild radish: Effects on several herbivores and plant fitness. Ecology 80: 1713

Agrawal AA, Strauss SY, Stout MJ (1999) Costs of induced responses and tolerance to herbivory in male and female fitness components of wild radish. Evolution 53: 1093

Alstad DN, Andow DA (1995) Managing the evolution of resistance to transgenic plants. Science 268: 1894
Andow DA (2002) Resisting resitance to $B t$ crops. In Letourneau DK, Burrows BE, eds, Genetically Engineered Organisms: Assessing Environmental and Human Health Effects. CRC Press, Boca Raton, FL, pp 99-121

Archer TL, Schuster G, Patrick C, Cronholm G, Bynum ED, Morrison WP (2000) Whorl and stalk damage by European and Southwestern corn borers to four events of Bacillus thuringiensis transgenic maize. Crop Protection 19: 181

Ashfaq M, Young SY, McNew RW (2000) Development of Spodoptera exigua and Helicoverpa zea (Lepidoptera: Noctuidae) on transgenic cotton containing CrylAc insecticidal protein. J. Entomol. Sci. 35: 360

Barbosa P (1993) Lepidopteran foraging on plants in agroecosystems: Constraints and consequences. In Stamp NE, Casey TM, eds, Ecological and Evolutionary Constraints on Foraging Caterpillars, pp 29

Barbosa P (1998) ed, Conservation Biological Control. Academic Press

Benbrook CM, Groth E, Halloran JM, Hansen MK, Marquardt S (1996) Pest Management at the Crossroads. Consumers Union, Yonkers, New York

Bergelson J (1994) Changes in fecundity do not predict invasiveness: A model study of transgenic plants. Ecology 75: 249

Bergelson J, Purrington CB (2002) Factors affecting the spread of resistant Arabidopsis thaliana populations. In Letourneau DK, Burrows BE, eds, Genetically Engineered Organisms: Assessing Environmental and Human Health Effects. CRC Press, Boca Raton, FL, pp 33

Betz FS, Hammond BG, Fuchs RL (2000) Safety and advantages of Bacillus thuringiensis-protected plants to control insect pests. Regul. Toxicol. Pharmacol. 32: 156173

Bourget D, Bethenod MT, Trouve C, Frederique V (2000) Host-plant diversity of the European corn borer Ostrinia nubilalis: What value for sustainable transgenic insecticidal Bt maize? Proc. R. Soc. Lond. B Biol. Sci. 267: 1177

Callaway RM, DeLuca TH, Belliveau WM (1999) Biological-control herbivores may increase competitive ability of the noxious weed Centaurea maculosa. Ecology $\mathbf{8 0}$ : 1196-1201

Caswell H (2001) Matrix Population Models. Sinauer, Sunderland, Massachusetts

Chèvre AM, Eber F, Baranger A, Hureau G, Barret P, Picault H, Renard M (1998) Characterization of backcross generations obtained under field conditions from oilseed rape wild radish F-1 interspecific hybrids - An assessment of transgene dispersal. Theor. Appl. Genet. 97: 90-98

Colwell RK, Norse EA, Pimentel D, Sharples FE, Simberloff D (1985) Genetic engineering in agriculture. Science 229: 111

Crawley M, Harvey PH, Purvis A (1996) Comparative ecology of the native and alien floras of the British Isles. 
Philos. Trans. R. Soc. Lond. B Biol. Sci. 351: 1251

Daehler CC, Strong DR (1996) Status, prediction and prevention of introduced cordgrass Spartina spp. Invasions in Pacific Estuaries, USA. Biol. Conserv. 78: 51-58

Darmency H (1994) The impact of hybrids between genetically modified crop plants and their related species - Introgression and weediness. Mol. Ecol. 3: 37-40

Doak DF (1991) The consequences of herbivory for dwarf fireweed: Different time scales, different morphological scales. Ecology 72: 1397

Doak DF (1992) Lifetime impacts of herbivory for a perennial plant. Ecology 73: 2086-2099

Dyer LA, Letourneau DK (1999) Trophic cascades in a complex terrestrial community. Proc. Natl. Acad. Sci. USA 96: 5072-5076

Ellstrand NC, Prentice HC, Hancock JF (1999) Gene flow and introgression from domesticated plants into their wild relatives. Annu. Rev. Ecol. Syst. 30: 539-563

Felton GW, Dahlman DL (1984) Allelochemical Induced Stress - Effects of L-canavanine on the pathogenicity of Bacillus thuringiensis in Manduca sexta. J. Invertebr. Pathol. 44: 187-191

Fitton MG, Shaw MR, Gauld ID (1988) Pimpline ichneumonflies, Hymenoptera, Ichneumonidae (Pimplinae). Handbook for the Identification of British Insects 7: 1

Fretwell SD (1977) The regulation of plant communities by food chains exploiting them. Perspect. Biol. Med. 20: 169

Geervliet JBF, Posthumus MA, Vet LEM, Dicke M (1997) Comparative analysis of headspace volatiles from different caterpillar-infested or uninfested food plants of Pieris species. J. Chem. Ecol. 23: 2935-2954

Hails RS (2000) Genetically modified plants - The debate continues. Trends. Ecol. Evol. 15: 14-18

Hauser TP, Shaw RG, Ostergard H (1998) Fitness of F-1 hybrids between weedy Brassica rapa and oilseed rape ( $B$. napus). Heredity 81: 429-435

Hedin PA, Lindig OH, Sikorowski PP, Wyatt M (1978) Suppressants of gut bacteria in the boll weevil from the cotton plant. J. Econ. Entomol. 71: 394-396

Hellmich RL, Siegfried BD, Sears MK, Stanley-Horn DE, Daniels MJ, Mattila HR, Spencer T, Bidne KG, Lewis LC (2001) Monarch larvae sensitivity to Bacillus thuringiensispurified proteins and pollen. Proc. Natl. Acad. Sci. USA 98: 11925-11930

Hilbeck A (2002) Transgenic host plant resistance and nontarget effects. In Letourneau DK, Burrows BE, eds, Genetically engineered organisms: assessing environmental and human health effects. CRC Press, Boca Raton, Florida, pp 33

Hoffman CA (1990) Ecological risks of genetic engineering of crop plants: scientific and social analyses are critical to realize benefits of the new techniques. Bioscience 40: 434

Hull LA, Beers EH (1985) Ecological selectivity: modifying chemical control practices to preserve natural enemies. In
Hoy MA, Herzog DC, eds, Biological Control in Agricultural IPM Systems. Academic Press, Inc., New York

James RR, Miller JC, Lighthart B (1993) Bacillus thuringiensis var. kurstaki affects a beneficial insect, the cinnabar moth (Lepidoptera: Arctiidae). J. Econ. Entomol. 86: 334

Jenczewski E, Ronfort J, Chèvre AM (2003) Crop-to-wild gene flow, introgression and possible fitness effects of transgenes. Environ. Biosafety Res. 2: 9-24

Jesse LCH, Obrycki JJ (2000) Field deposition of $B t$ transgenic corn pollen: lethal effects on the monarch butterfly. Oecologia 125: 241-248

Johnson KS, Scriber JM, Nitao JK, Smitley DR (1995) Toxicity of Bacillus thuringiensis var. kurstaki to three nontarget lepidoptera in field studies. Environ. Entomol. 24: 288-297

Jørgensen RB, Andersen B (1994) Spontaneous hybridization between oilseed rape (Brassica napus) and weedy Brassica campestris (Brassicaceae) - a rise of growing geneticallymodified oilseed rape. Am. J. Bot. 81: 1620-1626

Jørgensen RB, Andersen B, Landbo L, Mikkelsen TR, Dias JS, Crute I, Monteiro AA (1996) Spontaneous hybridization between oilseed rape (Brassica napus) and weedy relatives. Acta Hort. 407: 193

Juenger T, Bergelson J (1998) Pairwise versus diffuse natural selection and the multiple herbivores of scarlet gilia, Ipomopsis aggregata. Evolution 52: 1583-1592

Kareiva P, Morris W, Jacobi CM (1994) Studying and managing the risk of cross-fertilization between transgenic crops and wild relatives. Mol. Ecol. 3: 15-21

Kareiva P, Parker IM, Pascual M (1996) Can we use experiments and models in predicting the invasiveness of genetically engineered organisms. Ecology 77: 1670-1675

Klinger T (2002) Variability and uncertainty in crop-to-wild hybridization. In Letourneau DK, Burrows BE, eds, Genetically engineered organisms: assessing environmental and human health effects. CRC Press, Boca Raton, Florida, pp 1

Klinger T, Ellstrand NC (1994) Engineered genes in wild populations - Fitness of weed-crop hybrids of Raphanus sativus. Ecol. Appl. 4: 117-120

Koptur S (1990) Early season defoliation can affect Carex laxiflora Cyperaceae seed set in same year or reproductive allocation in subsequent years. Bull. Ecol. Soc. Am. 71: 217

Krishik VA, Barbosa P, Reichelderfer CF (1988) Three trophic level interactions: allelochemicals, Manduca sexta, and Bacillus thuringiensis var. kurstaki Berliner. Environ. Entomol. 17: 476-482

Kriticos D, Brown J, Radford I, Nicholas M (1999) Plant population ecology and biological control: Acacia nilotica as a case study. Biol. Control. 16: 230-239

Lefol E, Seguinswarts G, Downey RK (1997) Sexual hybridisation in crosses of cultivated Brassica species with the crucifers Erucastrum gallicum and Raphanus raphanistrum - 
Potential for gene introgression. Euphytica 95: 127-139

Letourneau DK, Hagen JA, Robinson GS (2002) Bt crops: Evaluating benefits under cultivation and risks from escaped transgenes in the wild. In Letourneau DK, Burrows BE, eds, Genetically Engineered Organisms: Assessing Environmental and Human Health Effects. CRC Press, Boca Raton, Florida, pp 33

Losey JE, Obrycki JJ, Hufbauer RA (2002) Impacts of genetically engineered crops on non-target herbivores: $B t$ corn and monarch butterflies as a case study. In Letourneau DK, Burrows BE, eds, Genetically Engineered Organisms: Assessing Environmental and Human Health Effects. CRC Press, Boca Raton, Florida, pp 143

Losey JE, Rayor LS, Carter ME (1999) Transgenic pollen harms monarch butterflies. Nature 399: 214

Louda SM (1999) Insect limitation of weedy plants and its implications. In Traynor PL, Westwood JH, eds, Conference Proceedings: Workshop on Ecological Effects of Pest Resistance Genes in Managed Ecosystems. Information Systems for Biotechnology, Bethesda, Maryland

Macintosh SC, Stone TB, Sims SR, Hunst PL, Greenplate JT, Marrone PG, Perlak J, Fischhoff DA, Fuchs RL (1990) Specificity and efficacy of purified Bacillus thuringiensis proteins against agronomically important insects. J. Invertebr. Pathol. 56: 258

Maron JL (1998) Insect Herbivory above- and below-ground Individual and joint effects on plant fitness. Ecology 79: 1281-1293

Marquis RJ (1984) Leaf herbivores decrease fitness of a tropical plant. Science 226: 537

Marquis RJ (1992) A bite is a bite is a bite? Constraints on response to folivory in Piper arietinum (Piperaceae). Ecology 73: $143-152$

Marvier M, Kareiva P (1999) Extrapolating from field experiments that remove herbivores to population-level effects of herbivore-resistant transgenes. In Traynor PL, Westwood JH, eds, Conference Proceedings: Workshop on Ecological Effects of Pest Resistance Genes in Managed Ecosystems. Information Systems for Biotechnology, Blacksburg, Virginia, http://www.nbiap.vt.edu

Mauricio R, Bowers MD, Bazzaz FA (1993) Pattern of leaf damage affects fitness of the annual plant Raphanus sativus (Brassicaceae). Ecology 74: 2066-2071

McCall PJ, Turlings TCJ, Loughrin J, Proveaux AT, Tumlinson JH (1994) Herbivore-induced volatile emissions from cotton (Gossypium hirsutum L.) seedlings. J. Chem. Ecol. 20: $3039-3050$

McNaughton SJ (1986) On plants and herbivores. Am. Nat. 128: 765

Messeguer J, Fogher C, Guiderdoni E, Marfa V, Catala MM, Baldi G, Mele E (2001) Field assessments of gene flow from transgenic to cultivated rice (Oryza sativa L.) using a herbicide resistance gene as tracer marker. Theor. Appl. Genet. 103: 1151-1159
Meyer GA (2000) Interactive effects of soil fertility and herbivory on Brassica nigra. Oikos 88: 433-441

Mikkelsen TR, Jensen J, Jorgensen RB (1996) Inheritance of oilseed rape (Brassica napus) RAPD markers in a backcross progeny with Brassica campestris. Theor. Appl. Genet. 92: 492-497

Mullin CA, Croft BA (1985) An update on development of selective pesticides favoring arthropod natural enemies. In Hoy MA, Herzog DC, eds, Biological Control in Agriculture IPM Systems. Academic Press, Inc., New York

Naber AC, Aarssen LW (1998) Effects of shoot apex removal and fruit herbivory on branching, biomass and reproduction in Verbascum thapsus (Scrophulariaceae). Am. Midl. Nat. 140: 42-54

National Research Council (2000) Genetically Modified PestProtected Plants: Science and Regulation. National Academy Press, Washington DC

National Research Council (2002) Environmental Effects of Transgenic Plants: The scope and adequacy of regulation. National Academy Press, Washington DC

Navon A (1993) Control of lepidopteran pests with Bacillus thruingiensis. In Entwistle PF, Cory S, Bailey MJ, Higgs S, eds, Bacillus thuringiensis, an environmental biopesticide: theory and practice. Wiley, Chichester England, New York, pp 311

Neeser C (1999) Report of the Brassica crops working group. In Traynor PL, Westwood JH, eds, Conference Proceedings: Workshop on Ecological Effects of Pest Resistance Genes in Managed Ecosystems. Information Systems for Biotechnology, Bethesda, Maryland

Obrycki JJ, Losey JE, Taylor OR, Jesse LCH (2001) Transgenic insecticidal corn: Beyond insecticidal toxicity to ecological complexity. Bioscience 51: 353-361

Parker IM (2000) Invasion dynamics of Cytisus scoparius: A matrix model approach. Ecol. Appl. 10: 726-743

Paulison MA (1987) Exploitation by, and the effects of, caterpillar grazers on the annual, Rudbeckia hirta (Compositae). Am. Midl. Nat. 117: 439

Peacock JW, Schweitzer DF, Carter JL, Dubois NR (1998) Laboratory assessment of the effects of Bacillus thuringiensis on native Lepidoptera. Environ. Entomol. 27: 450-457

Peferoen M (1997) Progress and prospects for field use of $B t$ genes in crops. Trends Biotechnol. 15: 173-177

Peterson G, Cunningham S, Deutsch L, Erickson J, Quinlan A, Raez-Luna E, Tinch R, Troell M, Woodbury P, Zens S (2000) The risks and benefits of genetically modified crops: A multidisciplinary perspective. Conserv. Ecol. 4: 38-49

Phipps RH, Park JR (2002) Environmental benefits of genetically modified crops: Global and European perspectives on their ability to reduce pesticide use. J. Anim. Feed. Sci. 11: $1-18$

Pilson D (1996) Two herbivores and constraints on selection for resistance in Brassica rapa. Evolution 50: 1492 
Pilson D (2000) Herbivory and natural selection on flowering phenology in wild sunflower, Helianthus annuus. Oecologia 122: $72-82$

Pilson D, Decker KL (2002) Compensation for herbivory in wild sunflower: Response to simulated damage by the headclipping weevil. Ecology 83: 3097-3107

Price PW (1992) Plant resources as the mechanistic basis for insect herbivore population dynamics. In Hunter MD, Ohgushi T, Price PW, eds, Effects of Resource Distribution on Animal-Plant Interactions. Academic Press, San Diego, California, pp 139

Reichelderfer CF (1991) Interactions among allelochemicals, some Lepidoptera, Bacillus thuringiensis Berliner. In Barbosa B, Kirschik VA, Jones CG, eds, Microbial Mediation of Plant-Herbivore Interactions. Wiley Press, New York

Robinson GS (1998) Bugs, hollow curves and species-diversity indexes. STATS - American Statistical Association 21

Robinson GS (1999) HOSTS - A database of the hostplants of the world's Lepidoptera. Nota Lepidopterologica 22: 35

Robinson GS, Ackery PR, Kitching IJ, Beccaloni GW, Hernandez LM (2001) Hostplants of the moth and butterfly caterpillars of the oriental region. Southdene Sdn Bhd, Kuala Lumpur

Robinson GS, Ackery PR, Kitching IJ, Beccaloni GW, Hernandez LM (2002a) Hostplants of the moth and butterfly caterpillars of America north of Mexico. Mem. Am. Entomol. Inst. 69: 1-824

Robinson GS, Ackery PR, Kitching IJ, Beccaloni GW, Hernandez LM (2002b) HOSTS - A database of hostplants of the world's Lepidoptera, http://www/nhm.ac.uk/entomology/hostplants/index.html

Royal Society of Canada (2001) An Expert Panel Report on the Future of Food Biotechnology. The Royal Society of Canada, Ottawa, Canada

Saxena D, Flores S, Stotzky G (1999) Insecticidal toxin in root exudates from Bt corn. Nature 402: 480

Schuster MR, Calderon M (1986) Interactions of host plant resistant genotypes and beneficial insects in cotton ecosystems. In Boethel DJ, Eikenbary RD, eds, Interaction of Host Plant Resistance and Parasitoids and Predators of Insects. Halstead Press, New York, pp 84-97

Sears MK, Hellmich RL, Stanley-Horn DE, Oberhauser KS, Pleasants JM, Mattila HR, Siegfried BD, Dively GP (2001) Impact of $B t$ corn pollen on monarch butterfly populations: A risk assessment. Proc. Natl. Acad. Sci. USA 98: $11937-11942$

Shea K, Kelly D (1998) Estimating biocontrol agent impact with matrix models: Carduus nutans in New Zealand. Ecol. Appl. 8: 824-832

Smith RA, Couche GA (1991) The phylloplane as a source of Bacillus thuringiensis variants. Appl. Environ. Microbiol. 57: 311

Snow AA, Andersen B, Jorgensen RB (1999) Costs of transgenic herbicide resistance introgressed from Brassica napus into weedy B. rapa. Mol. Ecol. 8: 605-615

Snow AA, Palma PM (1997) Commercialization of transgenic plants: Potential ecological risks. Bioscience 47: 206-206

Snow AA, Pilson D, Rieseberg LH, Paulsen MJ, Pleskac N, Reagon MR, Wolf DE, Selbo SM (2003) A Bt transgene reduces herbivory and enhances fecundity in wild sunflowers. Ecol. Appl. 13: 279-286

Song ZP, Lu BR, Zhu YG, Chen JK (2003) Gene flow from cultivated rice to the wild species Oryza rufipogon under experimental field conditions. New Phytol. 157: 657665

Srinivasan G, Babu PC (2001) Effects of Bacillus thuringiensis Berliner on predatory green lacewing, Chrysoperla carnea Stephens (Chrysopidae: Neroptera). Pestic Res. J. 13: 266-269

Stewart CN, All JN, Raymer PL, Ramachandran S (1997) Increased fitness of transgenic insecticidal rapeseed under insect selection pressure. Mol. Ecol. 6: 773-779

Story JM, Good WR, White LJ, Smith L (2000) Effects of the interaction of the biocontrol agent Agapeta zoegana L. (Lepidoptera: Cochylidae) and grass competition on spotted knapweed. Biol. Control 17: 182-190

Strauss SY, Siemens DH, Decher MB, Mitchell-Olds T (1999) Ecological costs of plant resistance to herbivores in the currency of pollination. Evolution 53: 1105-1113

Strong DR (1984) Density-vague ecology and liberal population regulation in insects. In Price PW, Slobodchikoff CN, Gaud WS, eds, Wiley, New York, pp 313

Strong DR (1992) Are trophic cascades all wet - Differentiation and donor-control in speciose ecosystems. Ecology 73: $747-754$

Tiedje JM, Colwell RK, Grossman YL, Hodson RE, Lenski RE, Mack RN, Regal PJ (1989) The planned introduction of genetically engineered organisms: ecological considerations and recommendations. Ecology 70: 298

Tscharntke T (1999) Insects on common reed (Phragmites australis): community structure and the impact of herbivory on shoot growth. Aquat. Bot. 64: 399-410

Turkington R, Klein E, Chanway CP (1993) Interactive effects of nutrients and disturbance - an experimental test of plant strategy theory. Ecology 74: 863-878

Turlings TCJ, Bernasconi M, Bertossa R, Bigler F, Caloz G, Dorn S (1998) The induction of volatile emissions in maize by three herbivore species with different feeding habits Possible consequences for their natural enemies. Biol. Control 11: 122-129

U N (1935) Genome-analysis in Brassica with special reference to the experimental formation of $B$. napus and peculiar mode of fertilization. Jap. J. Bot. 7: 389-452

van Frankenhuyzen K, Nystrom C (1999) The Bacillus thuringiensis toxin specificity database. http://www.glfc.cfs. nrcan.gc.ca/bacillus

van Frankenhuyzen K, Gringorten JL, Milne RE, Gauthier D, Pusztai M, Brousseau R, Masson L (1991) Specificity of activated Cryla proteins from Bacillus thuringiensis subsp. 
kurstaki Hd-1 for defoliating forest Lepidoptera. Appl. Environ. Microbiol. 57: 1650-1655

Volenberg DS, Hopen HJ, Campobasso G (1999) Biological control of yellow toadflax (Linaria vulgaris) by Eteobalea serratella in peppermint (Mentha piperita). Weed Sci. 47: 226-232

Wagner DL, Peacock JW, Carter JL, Talley SE (1996) Field assessment of Bacillus thuringiensis on nontarget lepidoptera. Environ. Entomol. 25: 1444-1454
Wolfenbarger LL, Phifer PR (2000) The ecological risks and benefits of genetically engineered plants. Science 290: 2088

Zangerl AR, McKenna D, Wraight CL, Carroll M, Ficarello P, Warner R, Berenbaum MR (2001) Effects of exposure to event 176 Bacillus thuringiensis corn pollen on monarch and black swallowtail caterpillars under field conditions. Proc. Natl. Acad. Sci. USA 98: 11908-11912 